\title{
A review of the health implications of heavy metals and pesticide residues on khat users
}

\author{
Albert M. Oyugi, Joshua K. Kibet ${ }^{*}$ (10 and John O. Adongo
}

\begin{abstract}
Background: There is an exponential rise in the use of farming chemicals in agricultural practices ostensibly to increase food production. The chewing of fresh khat leaves and shoots has spread across the world from ancient khat producing regions in East Africa and the Arabian Peninsula. Khat is a well-established socialization substance with stimulating characteristics. In this work, we have reviewed the deleterious impacts of several heavy metals such as lead, cadmium, iron in the khat plant and their health impacts. Survey on the health complications of farming chemicals used in khat production is also presented.

Main body of the abstract: The toxic effects of heavy metals and farming chemicals in plant matter such as khat leaves are a serious health concern. Heavy metals including cadmium (Cd) and lead (Pb), for instance, bio-accumulate in the body and the food chain as precursors for disease. It has been established that blood that has lead levels of 40-60 ug/dL is a precursor for serious health illnesses such as cardiac arrest and cancer. On the other hand, cadmium is reported to bind itself onto metallothioneins hence forming cadmium-metallothionein complex that is transported to all body organs causing deleterious cell damage. The entry of farming chemical into the food chain especially via the chewing of contaminated khat has been known to contribute to health problems such as cancer, hypertension and liver cirrhosis. khat is branded a 'substance of abuse' by the World Health Organization (WHO) because of the adverse health risks it causes to humans. Relevant articles published between 2010 and 2021, and archived in PubMed, Google Scholar, Medley, Cochrane, and Web of Science were used in this review.

Short conclusion: The health implications of heavy metals and farming chemicals arising from the consumption of contaminated khat shoots are a serious concern to the khat chewing community. Consequently, there is need to develop better farming practices that may minimize the absorption of heavy metals and farming chemicals by the khat plant. Information presented in this review is also important in sensitizing policy makers to advance control measures towards safer khat farming practices.
\end{abstract}

Keywords: Cancer, Contaminated khat, Liver cirrhosis, Pesticides, Hypertension

\section{Background}

Khat is a bushy plant whose leaves are chewed for their stimulating and euphoric effects (Gezon 2012). Generally, the chemical composition of khat and the variety to be grown depends on the geographical region, associated climatic conditions and favorability of the environment (Tadesse and Kebede 2015). Khat varieties differ in terms

\footnotetext{
*Correspondence: jkibet@egerton.ac.ke

Department of Chemistry, Egerton University, P.O Box 536, 20115 Egerton, Kenya
}

leaf color, size and the plant height (Atlabachew et al. 2010a, b). These features collectively make these varieties have different levels of pharmacological adaptation (Hailemariam et al. 2018). In intensely khat producing areas, domestic demand has gone up while international market has widened hence much of the khat shoots and fresh leaves are exported for foreign exchange (Belwal and Teshome 2011; Kandari et al. 2014; Tadesse and Kebede 2015). This has increased its market price and production in order to match the ever-rising demand of khat (Gebrehiwot et al. 2016). Figure 1 gives samples 

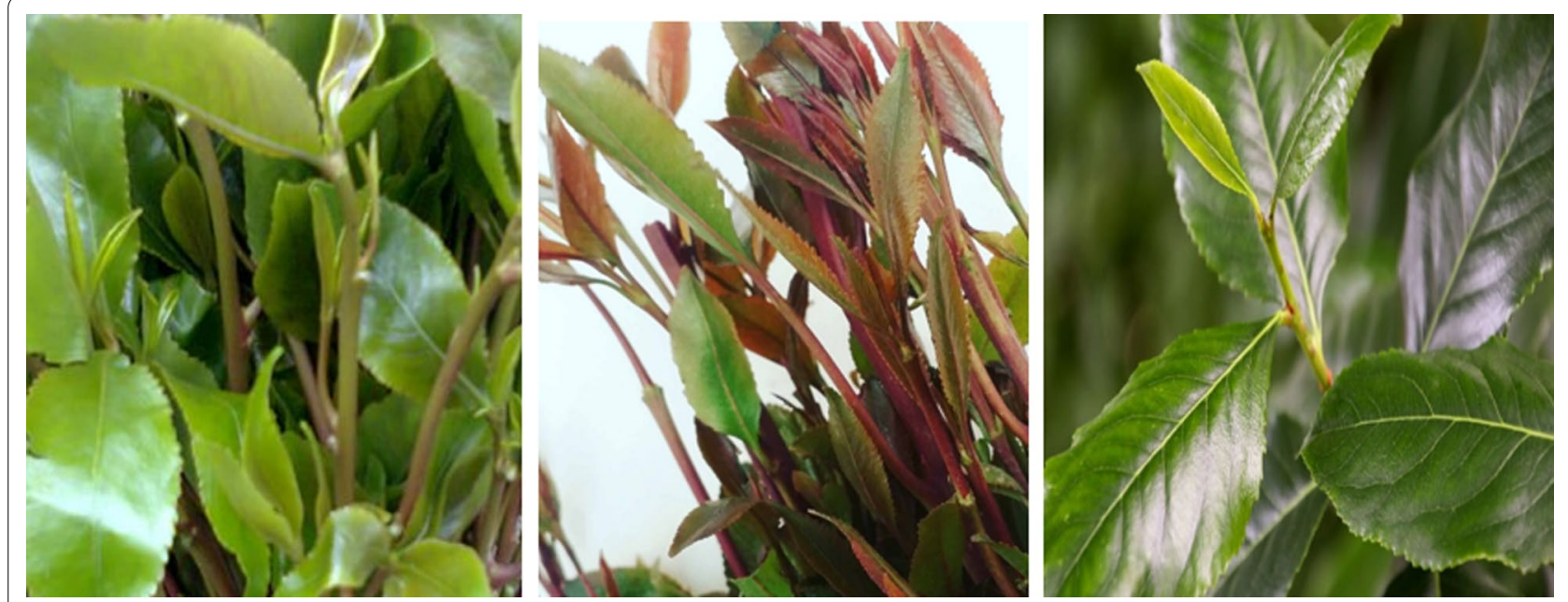

Fig. 1 Samples of fresh khat leaves and shoots- Adapted from Mandi 2019 and Oyugi et al. 2021

of khat leaves and shoots usually chewed. Besides khat being a recreational plant with medicinal effects, it is a foreign exchange earner and of significant economic value. For instance, its cultivation accounts for over $70 \%$ of farmer's income in the Ethiopian highlands of Oromia region (Kandari et al. 2014).

Khat chewing is considered a tradition as well as a social habit among the khat consuming communities (Ayano et al. 2019). Generally, khat is widely used for recreational purposes, psychological pleasure, and religious activities, and is known for its medicinal properties (al'Absi et al. 2013). Khat roots and leaves for instance are used to treat coughs, influenza and asthmatic conditions (Yimer and Khan 2015). Furthermore, khat intrusion is used to treat boils and premature ejaculation in men (Mohammed and Engidawork 2011a, b). Fresh leaves and shoots of the khat plant are chewed for their euphoric characteristics especially in Sub-Saharan Africa and parts of the Middle East including Yemen and Saudi Arabia (Al-Motarreb et al. 2002). Its use is particularly prevalent in Yemen, Djibouti, Kenya, Ethiopia, Eritrea, Somalia and Uganda (Al-Motarreb et al. 2002; Thomas and Williams 2013). Nonetheless, khat has also spread to other countries such as Madagascar courtesy of immigrants. For instance, khat arrived in Madagascar with Yemeni dock workers in the early twentieth century and is presently an economic crop grown mainly in Northern Madagascar (Gezon 2017).

Nonetheless, regular khat intake specifically in the form of chewing is reported to have a close association with or increased susceptibility to hypertension (Atlabachew et al. 2011; Nigatu and Libsu 2019), increased pulse rate and liver problems (Getahun et al. 2010; Kassab and $\mathrm{Al}$ Moustafa 2017). Chewing of khat leaves and use of khat products contaminated with pesticides remnants and heavy metals has been confirmed to increase the risk of cardiovascular complications such as oxidative stress and cardiac arrest (Atnafie et al. 2021). Consumption of khat contaminated with $\mathrm{Cd}$ over time can lead to bioaccumulation of this metal in the body of a khat chewer. Accordingly, elevated levels of cadmium (Cd) in blood are associated with increased blood pressure although the mechanism by which this occurs is yet to be understood (Swaddiwudhipong et al. 2010; Garner and Levallois 2017). Equally important, the non-biodegradable nature of lead $(\mathrm{Pb})$ makes it potent if it bio-accumulates in the human body for long periods, and may consequently cause nervous breakdown, high blood pressure, cardiovascular diseases and cancer lesions (Flora et al. 2012). Remarkably, blood that has Pb levels of 40-60 $\mathrm{ug} / \mathrm{dL}$ amounts to severe health problems unless urgent treatment measures are considered (Flora et al. 2012). Accordingly, this review paper is very important in articulating issues of concern such as heavy metals detected in khat resulting from possible use of fertilizers, composite manures and pesticides. Concentrations of heavy metals in khat products show permissible limits as per World Health Organizations and Food Agricultural Organization (WHO/FAO) that may not cause adverse health challenges, but bio-accumulation from khat use can cause risk health effects. Besides, this review gives a detailed description of health diseases such as liver cirrhosis, cancer and hypertension that are life threatening, and can be associated with khat related activities-chewing and smoking of khat. This has created a potential health crisis in the form of human poisoning through consumption of farming chemical and heavy metals bioaccumulated in khat leaves. 
On the other hand, since there is no regulation on the limit of pesticide use especially in developing countries (Hassan et al. 2016), farmers use various chemicals which may contain toxic trace elements in order to boost production, and to match the demand of both local and international khat markets. The presence of heavy metals such as lead $(\mathrm{Pb})$, cadmium $(\mathrm{Cd})$, zinc $(\mathrm{Zn})$, copper $(\mathrm{Cu})$, nickel $(\mathrm{Ni})$ and chromium $(\mathrm{Cr})$ in edible parts of khat is well-documented in literature (Atlabachew et al. 2010a, b; Ashenef et al. 2014; Fenta and Kidanemariam 2015; Nigatu and Libsu 2019). Although their detectable concentration limits are low (Ashenef et al. 2014), their continuous bio-accumulation in the biological system is detrimental.

\section{Methodology}

In this review, literature published in the English language was considered. Databases such as the Web of Science, PubMed, Cochrane, Google Scholar, Medley, and published reports were employed in search of relevant terms-khat, insecticides and pesticides, khat chewing, farming chemicals, heavy metals, toxicity, cancer, liver damage and hypertension. Detailed literature search was analyzed online from December 2020 to May 2021 according to the procedures described in previous literature survey protocols (Palmatier et al. 2017). The authors set the online databases to provide notifications of search output that contained information matching the established search standards: PubMed, Science direct, Medley, Cochrane, and Google scholar. The information was saved on personal computers (PCs) and analyzed from a bibliometric perspective.

\section{Main text}

Besides the potential health risks that would be associated with substance abuse arising from excessive consumption of khat, there exists possible adverse problems associated with farming methods and practices involving wrong and or excessive pesticide applications. The chewing of khat is associated with serious health conditions such as cancer, hypertension and liver cirrhosis. This can partly be attributed to excessive consumption of unsafe khat that is potentially contaminated with farming chemicals and heavy metals. The chemical constituents of khat remain largely unknown to government authorities and the khat chewing community. Herein, we examine the health challenges faced by khat consumers as a result of chewing of khat contaminated with toxic trace metals and farming chemicals. The relationship between diseases such as hypertension, liver damage, and cancer cannot, however; be linked to the chemicals found in khat alone. There is sufficient evidence based on this review that the absorption of trace metals and pesticides by the khat plant can result in serious health consequences among the Khat consuming community. Notably, the use of cheap synthetic pesticides by farmers has gained traction as a quick means to manage pests in farms and increase the supply of food across the world (Daba et al. 2011; Karunamoorthi et al. 2012; Bempah et al. 2012; Krueger and Mutyambai 2020). This has not only increased food production but also precipitated an increase in health problems (Adamu et al. 2020). For instance, most pesticides used such as organochlorines are less expensive, versatile to majority of pests but exhibit persistency in the environment and is responsible for grave ailments including neurological injuries and endocrine disorders (Bempah et al. 2012). It is therefore important to note that the khat plant is susceptible to weeds, pest attack (Atlabachew et al. 2010a, b), and insect causing diseases, thus the applications of fertilizers and pesticides is necessary (Atlabachew et al. 2010a, b; Tadesse and Kebede 2015). Pesticides are believed to protect khat plants from diseases and pest attack (Hassan et al. 2016) whereas the application of fertilizers to increase khat yield is always in the rise (Masoud et al. 2012; Naji et al. 2015; Weyesa 2021). Nonetheless, unregulated application of pesticides can be hazardous because of their toxicity characteristics, environmental persistence and stability (Tiryaki and Temur 2010; Masiá et al. 2015). These chemicals are precursors for serious health problems over long time exposure. They are responsible for the introduction of trace metals into the soil (Woldamanuel 2019). These trace metals eventually enter khat plants and are ultimately absorbed into the biological systems of khat users with possible harm (Matloob 2003). Recent research has shown that use of pesticides and insecticides may result in human poisoning; denaturization of biologically essential enzymes and general environmental pollution (Masoud et al. 2012; Hassan et al. 2016; Regassa and Regassa 2018). The world health organization (WHO) reports an annual pesticide poisoning cases load of about 1-5 million people with fatalities in excess of 20,000 per annum (Karunamoorthi et al. 2012; Weyesa 2021). These statistics correlates with high levels of pesticide toxicity in agricultural products such as khat leaves (Hassan et al. 2016). Several common pesticides used extensively in agriculture, and horticulture in the past contained significant concentrations of metals-for instance in the recent past, about $10 \%$ of the chemicals approved for use as insecticides and fungicides in the United Kingdom (UK) were based on compounds which contain $\mathrm{Cu}, \mathrm{Hg}, \mathrm{Mn}, \mathrm{Pb}$, or $\mathrm{Zn}$ (Wuana and Okieimen 2011).

The soils where khat is grown can be weakly acidic or basic with $\mathrm{pH}$ values estimated in the range of 6.0-8.8 (Fenta and Kidanemariam 2015). Soils naturally contain 
both essential and non-essential elements and therefore through active transport, toxic lead $(\mathrm{Pb})$, cobalt $(\mathrm{Co})$ and cadmium $(\mathrm{Cd})$ ions are taken up and may bio-accumulate in different parts the khat plant (Tadesse and Kebede 2015). Heavy metals end up in the soil structure via modern agricultural practices although some of these metals exist naturally in soils (Tadesse and Kebede 2015). The concentration of trace metals in the soil determines the uptake levels by the plant (Tadesse and Kebede 2015). The uptake of toxic heavy metals and other elements in elevated levels enter the food chain hence are responsible for adverse health effects in the life of living organisms especially higher order animals such as man (Tadesse and Kebede 2015).

\section{Economic importance of khat}

Since the benefits of khat are high in terms of income; farmers tend to encroach to natural forests to plant this new cash crop (Dessie and Kinlund 2008). Moreover, as a result of attractive economic benefits, Khat farmers have gone to the extent of using chemical pesticides to boost production which unfortunately contaminates the khat leaves and shoots which are usually sought after for their amphetamine like stimulants (Derso and Dagnew 2019).

Khat cultivation and products greatly contribute to personal income accrued from sales and national economies gross domestic product through export (Patel 2015). They tend to be associated with high demand and increased willingness to pay and hence high returns for farmers, resulting in enhanced household economic flexibility (Gezon 2017; Yahya et al. 2016). Khat farmers and other entities have shown that khat is much better in terms of good returns (Table 1) compared to other wellestablished crops-coffee and tea (Carrier 2008). Khat production in Kenya, Ethiopia and Yemen is important because it contributes to the economic growth in addition to offering a wide range of employment opportunities to farmers and traders both directly and indirectly (Megerssa et al. 2014; Njiru et al. 2013; Teklie et al. 2017).
The high demand for khat across the world has made farmers use other farming methods to boost production in order to match demand needs (Woldamanuel 2019; Wondemagegn et al. 2017; Yimer and Khan 2015). Besides, high profits accrued from this crop were previously estimated at about 2.7 times more than that of other cereal crops such as maize and beans (Feyisa and Aune 2003). Khat is branded "green gold" in Northern Madagascar and hence its economic viability has enabled households to acquire other items using lots of cash from the sale of Khat (Gezon 2017). In Ethiopia, khat now ranks as one of the country's most valuable exports earner with an income estimated at US\$80 million in 2005 (Gebissa 2008; Mekuria 2018). Somaliland on the other hand collected approximately US $\$ 5.5$ million in khat import taxes in 2005, which means that khat revenues make up around 30 percent of the country's budget. These figures might have increased over time because of the legal status khat enjoys in these countries. In Mbeere sub county region in Eastern Kenya, farmers receive an income of about US\$20,000 per year (Njiru et al. 2013). In Yemen, khat generates about a third of the country'1s gross domestic product (Lamina and Lamina 2013). About a decade ago, a bunch of $200 \mathrm{~g}$ of khat leaves could easily be purchased in the UK for $£ 3.00$ (Pickering 2010), although currently khat can be bought online. From these statics, it can be inferred that khat cultivation is a lucrative business notwithstanding the health challenges associated with it.

There is supposition that Khat growers have better living standards in terms of yearly expenditure on food versus family's income and furthermore are able to meet other family needs (Feyisa and Aune 2003) although this is debatable. Reports show that in Kenya, other crop farmers are shifting into Khat cultivation because it has extremely high total annual income compared to other crops (Njiru et al. 2013). This involves applying modern farming technologies to maximize production. Khat producers are less affected by seasonal fluctuations in

Table 1 Some data on the prevalence of khat consumption in different countries where khat is prevalent

\begin{tabular}{|c|c|c|c|c|}
\hline Country of study & Type of study & Population segment & $\begin{array}{l}\text { Prevalence } \\
\text { of khat } \\
\text { consumption (\%) }\end{array}$ & References \\
\hline Ethiopia & $\begin{array}{l}\text { Systematic review and meta- } \\
\text { analysis }\end{array}$ & University students & 23.22 & Gebrie et al. (2018) \\
\hline Djibouti & $\begin{array}{l}\text { Cross-sectional epidemiological } \\
\text { survey }\end{array}$ & Patients (129) & 48.1 & Bennani and Mohamed (2021) \\
\hline Eastern region, Kenya & Cross-sectional household survey & Individuals above 10 years & 36.8 & Ongeri et al. (2019) \\
\hline Jazan region, Saudi Arabia & Cross-sectional survey & Students ( $15-25$ years) & 21.4 & Ageely (2009) \\
\hline Kisenyi, Uganda & Cross-sectional study & Male adults & 5.53 & Abdinasir (2013) \\
\hline
\end{tabular}


weather conditions and therefore khat growing can alleviate hunger and poverty (Ruder 2018). High prevalence of Khat use has increased daily consumption rates as a result of high income gains which has motivated farmers to adopt any unconventional methods including the use of banned farm chemicals in order to increase production. Generally, farmers cultivating khat receive higher prices for the sale of khat when compared to other alternative forms of merchandise (Gudata et al. 2019).

\section{Prevalence of khat consumption}

In countries such as Djibouti, men are significantly associated with high consumption of khat hence hinders economic and social status of the society. Consequently, resulting problems on oral hygiene such as dental carriers has been reported among regular khat users (Bennani and Mohamed 2021). It stands out that an estimated $90 \%$ of its population consume khat on a regular basis (Al-Maweri et al. 2018). In Ethiopia, prevalence of khat use is high mostly among university students at $23.22 \%$. This has been the concern as it is being promoted by factors such as family chewing practice, alcohol drinking and peer pressure (Gebrie et al. 2018). Additionally, Jazan region in Saudi Arabia reported a lifetime khat chewing prevalence at 33.2\% (Al-Maweri et al. 2018). Moreover, Kenya's khat consumption statistics are quite high since the crop enjoys a good legal status hence its export contributes to the growth in Kenya's economy (Ongeri et al. 2019). Table 1 gives a summary of prevalence of khat among khat users in different countries.

High prevalence to khat could be attributed to factors such as place of residence and gender (Ageely 2009). In places such as Kisenyi, Uganda, it turns out that factors such as family history of khat use and availability of khat plays a role in prevalence to khat use. Notably, the social norms and diversity in culture where khat is consumed plays a critical role in the prevalence khat (Abdinasir 2013). Table 1 demonstrates that khat chewing habit is widely spread in Yemen confirming it as being an integral part of their social life with studies pointing out that women practicing this routine is on the rise (Sadeq-Ali and AlAkhali 2017). In Kenya, it has been reported that khat is consumed regularly as it enables khat users to be active, stimulates their brains and relieves stresses (Njuguna et al. 2013). Also, khat has been chewed for a long time in Harar city and its effects are evident as compared to other parts of Ethiopia because of its long history of khat cultivation and consumption (Gudata et al. 2019). In Ethiopia and other countries in eastern Africa, khat abuse is an ever increasing public health problem-accordingly, the lifetime rate of chewing khat especially among women in Ethiopia is significant and is related to specific sociodemographic risks (Yitayih and van Os 2021).

\section{Medicinal and biological uses of khat}

Khat can act as an immunosuppressant. The major compound in Khat-cathinone $(0.625-1.25 \mathrm{mg} / \mathrm{kg})$ plays a critical role in suppressing undesirable immune response against pathogens that cause disease although is a wellestablished stimulant (Ketema et al. 2015). A khat chewer is estimated to chew $50-200 \mathrm{~g}$ of fresh khat daily (AlBayaty et al. 2011; Attafi et al. 2018) which is equivalent to $5 \mathrm{mg}$ amphetamine oral dosage (Ali et al. 2010) leading to a high intake of alkaloid chemicals (Attafi et al. 2018) with possible adverse health consequences such as high blood pressure, stroke, kidney failure and cardiac arrest. Moreover, high dose of khat of more than 500 g/week has the ability to expressively decrease sperm quality, testosterone levels (Mohammed and Engidawork 2011a,b), and in may cause male infertility as demonstrated in a research done on baboons (Gorfu 2006; Nyachieo et al. 2013). It is also important among pregnant women because chewing Khat improves their intimacy and ultimately boosting relationships with their spouses in addition to enabling them cope with stress related to pregnancy challenges (Mekuriaw et al. 2020). Structural resemblance of alkaloid chemicals found in khat especially cathinone with amphetamine has demonstrated immunomodulatory roles in immunosuppressive (infectious) diseases such as tuberculosis (Alvi et al. 2014). Mild khat use (lower doses of khat extract) plays an important role in promoting production of testosterone levels that enhances sexual activities in men (Mohammed and Engidawork 2011a,b). Table 2 shows a summary of confirmed biological properties of khat extracts and their associated benefits to biological tissues.

Treatment with cathinone compound is useful in the management of obesity occasioned by consumption of high-fat dietary considered a major health problem among many people across the world. Furthermore, khat extracts can reduce weight gain as noted in studies using animal models through activation of lipolysis present in adipose tissues (Alshagga et al. 2020). Potent antioxidative activity of khat makes it a potential candidate in medical applications and in food industry with the possibility of serving as a reference standard antioxidant capacity (Dudai et al. 2006). Remarkably, extracts from khat leaves and shoots have shown antidepressant properties that are important in the treatment of asthmatic conditins (Alfaifi et al. 2017). 
Table 2 Some biological uses of khat

\begin{tabular}{|c|c|c|c|c|}
\hline Form of Khat used & Study specimen & $\begin{array}{l}\text { Confirmation property of } \\
\text { Khat under investigation }\end{array}$ & Perceived body benefits & Reference \\
\hline Khat ethanolic extract & $\begin{array}{l}\text { Animal models (male albino } \\
\text { mice) }\end{array}$ & Antidepressant properties & Cure diseases such as asthma & Alfaifi et al. (2017) \\
\hline Fresh Khat shoots & Pregnant women & Enhances intimacy & $\begin{array}{l}\text { Relieves pregnancy related } \\
\text { stresses and boosts intimacy }\end{array}$ & Mekuriaw et al. (2020) \\
\hline Fresh Khat leaves & Adult mice & Reduce gain in body weight & $\begin{array}{l}\text { Obesity management and } \\
\text { reduction in body weight }\end{array}$ & Alshagga et al. (2020) \\
\hline Khat extract and cathinone & Swiss albino mice & Immunomodulatory roles & $\begin{array}{l}\text { Helps in combating infectious } \\
\text { diseases }\end{array}$ & Ketema et al. (2015) \\
\hline Khat extract and/or cathinone & Sprague-Dawley rats & $\begin{array}{l}\text { Promote production of } \\
\text { testosterone levels }\end{array}$ & Enhance sexual activity & $\begin{array}{l}\text { Mohammed and } \\
\text { Engidawork (2011a, } \\
\text { b) }\end{array}$ \\
\hline
\end{tabular}

\section{Heavy metals in blood samples}

Whole blood is the preferred specimen for detecting exposure to toxic heavy metals such as lead ( $>95 \%$ bound to erythrocytes) that are tightly bound to intracellular proteins (Karri et al. 2016; Keil et al. 2011). Besides, blood is also the preferred sample for detecting a mercury exposure because the most toxic forms of mercury such as dimethylmercury and diethylmecury are not usually eliminated in the urine (Anyanwu et al. 2018; Keil et al. 2011). Heavy metals in the environment are not degradable and can enter into the plant and animal biological system chiefly through air, water and soil and ultimately accumulated in the human body through food chain including khat chewing (Lia et al. 2019). A significant body of knowledge suggests that exposure to multiple diverse heavy metals and metal mixtures can have serious neurotoxic effects (Alrobaian and Arida 2019; Cusick et al. 2018; Karri et al. 2016). Lead exposure, for instance, is known to cause intellectual deficit, neurodevelopmental delay, and increased risk for cognitive disorders including Attention Deficit Hyperactivity Disorder (ADHD) (Canfield et al. 2005; Cusick et al. 2018). Besides, manganese in excess causes direct damage to neuronal cells (Cusick et al. 2018; Yin et al. 2018), while arsenic toxicity in drinking water has been shown to be dose dependent, and inhibit antioxidant activity and increase oxidative stress in the brain (Cusick et al. 2018; Jomova et al. 2011).

Blood transfusions among children especially those of extremely low birth weight are at risk of lead exposure (Bearer et al. 2000; White et al. 2019). A study conducted in Dhaka, Bangladesh, assessed the potential health risks caused by heavy metals on workers working in the plastic industry and showed that lead was found in high concentrations in the blood (Ahmed et al. 2020). It is important to note that the International Agency for Research on Cancer (IARC) has labeled cadmium (Cd) as a group 1 carcinogen to humans, and lead $(\mathrm{Pb})$ is a group $2 \mathrm{~A}$ possible human carcinogen (Ahmed et al. 2020). Changes in blood cells visible under a microscope or deletion of dense lines in the bones of children as can be observed through X-ray are signs used for detecting lead poisoning (Wani et al. 2015). As of 2012, the Centers for Disease Control and Prevention (USA) set the standard for elevated blood lead level for adults as $10 \mu \mathrm{g} / \mathrm{dL}$ and for children $5 \mu \mathrm{g} / \mathrm{dL}$ of the whole blood (Wani et al. 2015; CDC 2012). Beyond these limits, the system breaks down and the consequences may be fatal (Wani et al. 2015). Lead poisoning in humans damages the kidneys, liver, heart, brain, skeleton and the nervous system which is usually accompanied initial symptoms such as headache, dullness, memory loss and being irritable (Kinuthia et al. 2020; Flora et al. 2012).

In France (Table 3), whole blood samples were taken from 106 subjects-the blood samples were analyzed for a range of heavy metals because of their potential toxicity in humans, and for information regarding clinical concern and public interest, but also for use in industrial hygiene monitoring (Cesbron et al. 2013). In recent years coupled with industrialization, China is a serious case of heavy metal pollution in the world (Lia et al. 2019). As can be noted in Table 3, a high level of lead was noted in blood samples among the inhabitants of the Pearl River delta in China (Lia et al. 2019). Lead toxicity, for instance, is an important environmental disease whose effects on the human body are devastating because there is almost no function in the human body which is not affected by lead toxicity (Wani et al. 2015). Although each metal exhibits unique toxicology, there are common mechanisms of toxicity to include mimicry, oxidative damage, and adduct formation with DNA or protein, for instance; non-essential metals may mimic the essential metals thus causing cellular damage, endocrine disruption, and enzymatic damage (Keil et al. 2011). 
Table 3 Selected heavy metal concentrations in blood from various countries

\begin{tabular}{|c|c|c|c|c|}
\hline Country & Target group & Heavy metal in blood & $\begin{array}{l}\text { Heavy metal level in blood } \\
(\%)\end{array}$ & References \\
\hline \multirow[t]{6}{*}{ Uganda } & Children & Antimony & 99.0 & Cusick et al. (2018) \\
\hline & & Lead & 97.0 & \\
\hline & & Manganese & 36.4 & \\
\hline & & Cobalt & 19.2 & \\
\hline & & Cadmium & 17.0 & \\
\hline & & Copper & 12.0 & \\
\hline Country & Target group & Heavy metal in blood & $\begin{array}{l}\text { Heavy metal level in blood } \\
\mu \mathrm{g} \mathrm{L}^{-1}\end{array}$ & References \\
\hline \multirow[t]{4}{*}{ Bangladesh } & Industrial workers & Lead & $32.78 \pm 9.47$ & Ahmed et al. (2020) \\
\hline & & Zinc & $9.08 \pm 1.95$ & \\
\hline & & Nickel & $1.42 \pm 1.01$ & \\
\hline & & Cadmium & $1.08 \pm 0.47$ & \\
\hline Country & Target group & Heavy metal in blood & $\begin{array}{l}\text { Heavy metal level in blood } \\
\left(\mu \mathrm{g} \mathrm{L}^{-1}\right)\end{array}$ & References \\
\hline \multirow[t]{9}{*}{ India } & $0-30$ years & Arsenic & $2.45 \pm 1.72$ & Jose and Ray (2018) \\
\hline & & Lead & $31.6 \pm 12.5$ & \\
\hline & & Mercury & $1.31 \pm 0.83$ & \\
\hline & $31-45$ years & Arsenic & $2.05 \pm 1.45$ & Jose and Ray (2018) \\
\hline & & Lead & $29.8 \pm 16.3$ & \\
\hline & & Mercury & $1.87 \pm 1.42$ & \\
\hline & $45-60$ years & Arsenic & $1.54 \pm 1.00$ & Jose and Ray (2018) \\
\hline & & Lead & $41.0 \pm 12.7$ & \\
\hline & & Mercury & $1.52 \pm 1.55$ & \\
\hline Country & Target group & Heavy metal in blood & $\begin{array}{l}\text { Heavy metal level in blood } \\
\left(\mu \mathrm{g} \mathrm{L}^{-1}\right)\end{array}$ & References \\
\hline \multirow[t]{5}{*}{ France } & Adults & Arsenic & 0.02 & Cesbron et al. (2013) \\
\hline & & Lead & 2.26 & \\
\hline & & Mercury & 0.05 & \\
\hline & & Cadmium & 0.06 & \\
\hline & & Copper & 7.00 & \\
\hline Country & Target group & Heavy metal in blood & $\begin{array}{l}\text { Heavy metal level in blood } \\
\left(\mu \mathrm{g} \mathrm{L}^{-1}\right)\end{array}$ & References \\
\hline \multirow[t]{6}{*}{ China } & $\begin{array}{l}\text { Inhabitants of Pearl River } \\
\text { delta }\end{array}$ & Zinc & $11.50 \pm 8.03$ & Lia et al. (2019) \\
\hline & & Copper & $0.67 \pm 0.09$ & \\
\hline & & Chromium & $92.83 \pm 32.63$ & \\
\hline & & Lead & $158.84 \pm 160.38$ & \\
\hline & & Mercury & $1.19 \pm 1.40$ & \\
\hline & & Antimony & $1.92 \pm 1.09$ & \\
\hline
\end{tabular}

In general, havy metals are defined as those having a specific density of more than $5 \mathrm{~g} / \mathrm{cm} 3$ such as lead, mercury, aluminum, arsenic, cadmium and nickel (Alissa and Ferns 2011). With toxic load becoming an increasingly serious clinical problem, accurate evaluation is very important for not only determining and tracking interventions such as accepted tests for metal toxicity, which often rely on blood and urine, and are known to be mainly useful only for acute exposure butare unreliable for body toxic load (Pizzorno 2015). Heavy metal 
toxic load (HMTL) measures the amount of toxic heavy metal present in the biological system that impacts the human health and provides an idea to the regulatory health authority about the extent of damage on the organism (Saha and Paul 2019). Heavy metals become toxic when they are not metabolised by the body system and bio-accumulate in the soft tissues (Alissa and Ferns 2011; Jose and Ray 2018). The general symptoms of heavy metal poisoning include diarrhea, nauea, abdominal pain, tingling in the hands and feet, shortness of breath, confusion, general weakness and pass out(Järup 2003).

\section{Heavy metal residues in khat products}

Generally, heavy metals are non-biodegradable and are therefore precursors for long-term chronic toxicity in animals and humans (Al Bratty et al. 2019). Heavy metals or trace metals in khat products may occur because of regular use of fertilizers, incineration of scrap of metals (Ashenef et al. 2014) and application of pesticides (Atlabachew et al. 2011; Fenta and Kidanemariam 2015). Heavy metals can also be absorbed by the khat plant from contaminated soils (Al Bratty et al. 2019). Ultimately, long term health risks of heavy metal exposure from both occupational and environmental settings involve multiorgan toxicities including disturbances of the nervous system, cognitive faculties, and homeostatic processes, immune system dysregulation, carcinogenesis and possible permanent disabilities (Offor et al. 2021). Previous research reported that chewable and commercially consumable Ethiopian khat products showed the presence of heavy metals such as $\mathrm{Zn}, \mathrm{Co}, \mathrm{Cu}, \mathrm{Cr}$ and $\mathrm{Fe}$ (Tadesse and Kebede 2015; Yimer and Khan 2015). Moreover, another study in Yemen showed khat contained significant concentrations of $\mathrm{Zn}, \mathrm{Cu}, \mathrm{Pb}$ and $\mathrm{Cd}$ metals (Matloob 2003). This is because the khat plant has the ability to accumulate essential minerals for its growth and non-essential minerals (mostly trace metals) which have no role in its growth (Atlabachew et al. 2011). These metals can be determined and analyzed from various khat samples by the use of various techniques such as inductively coupled plasma-mass spectroscopy technique (ICP-MS), X-ray fluorescence spectroscopy (XRF) (Al Bratty et al. 2019) and flame atomic absorption spectrometry (Yimer and Khan 2015; Woldamanuel 2019).

Farming of food crops including khat and vegetables in contaminated environments are periodically done by small scale farmers using fertilizers and banned farm chemicals to maximize yields this may cause a steady accumulation of heavy metals in the African environment which may exceed the World Health Organization permissible limits (Anyanwu et al. 2018). Toxic heavy metals such as arsenic (As), lead $(\mathrm{Pb})$, and mercury $(\mathrm{Hg})$ are systemic toxicants that are detrimental to human healththese elements are increasing in the environment due industrialization and chemicalized agricultural activities, accumulation of these metals in human biological system (Jose and Ray 2018). The amount of $\mathrm{As}, \mathrm{Pb}$, and $\mathrm{Hg}$ in blood samples of the selected individuals was analyzed to show the influence of age on heavy metal accumulation as noted in Table 4 .

Table 4 reports that plants including khat can bio-accumulate both essential and non-essential elements from the environment with the later having no direct benefit to the plant (Atlabachew et al. 2011). Soils enriched with fertilizers have a higher content of heavy metals than the natural soils. Proportionate application of pesticides also increases their concentration in soils with the possibility of high uptake by the plant and consequent entry into the food chain (Tadesse and Kebede 2015). Notably, the concentration of heavy metals in plants including Khat influence factors such as concentration in soil, geographical variations, applications of pesticides and fertilizers, prevailing regional climatic conditions (Atlabachew et al. 2011) and their associated atmospheric deposition (Tadesse and Kebede 2015).

Although fresh leaves of khat are customarily chewed to achieve metal stimulation, the long term use of abuse

Table 4 Adverse health effects associated with toxic levels of selected heavy metals

\begin{tabular}{|c|c|c|c|}
\hline Health effects & $\begin{array}{l}\text { Physiological symptoms associated with the } \\
\text { heavy metal }\end{array}$ & $\begin{array}{l}\text { Heavy metals } \\
\text { determined in } \\
\text { khat }\end{array}$ & References \\
\hline Cardiovascular diseases & Heart rate increase, Dry mouth, Blurred vision & $\mathrm{Pb}, \mathrm{Cd}, \mathrm{Cu}$ & Chowdhury et al. (2018) \\
\hline Gastrointestinal disorders & Diarrhea, Nausea, Vomiting, Abdominal pain & $\mathrm{Cu}, \mathrm{Mn}, \mathrm{Fe}, \mathrm{Co}, \mathrm{Cd}$ & $\begin{array}{l}\text { Pizzaro et. al. (1999), Sane et al. (2018), Leyssens et. } \\
\text { al. (2017), Lia et al. (2019), Tinkov et al. (2018) }\end{array}$ \\
\hline Reproductive disorders & Hampered fetal growth, Fertility disorders & $\mathrm{Pb}$ & Kumar et al. (2020) \\
\hline Carcinogenic effects & Tumor growth & $\mathrm{Cd}$ & Genchi et al. (2020) \\
\hline Neurological disorders & $\begin{array}{l}\text { Reduced intelligence quotient }(\mathrm{IQ}) \text { in children, } \\
\text { Mental retardation, Behavioral disorders, Suicide } \\
\text { attempts }\end{array}$ & $\mathrm{Pb}, \mathrm{Cu}, \mathrm{Mn}, \mathrm{Fe}$ & $\begin{array}{l}\text { WHO (2019), Santos et. al. (2019), Dobson et al. } \\
\text { (2004), Sane et al. (2018) }\end{array}$ \\
\hline
\end{tabular}


can be associated with numerous of health problems and conditions that are related to the deposition of its residual compounds and elements in the human blood system. Studies have shown that khat can potentially bio-accumulate heavy metal ions in its soft plant tissues during cultivation system (Jose and Ray 2018). Therefore, long term consumption can predispose perennial khat chewers to a host of some of the adverse health conditions that are related to heavy metal ion accumulation, toxicity and or poisoning. Table 4 gives a summary of selected surveys and clinical diagnostic and studies on the adverse health risks associated with heavy metal toxicities. The health complications such as cardiovascular disease, gut disorders, reproductive disorders, cancers and neurotoxicity are among the common biological effects or health conditions that have been associated with heavy metal accumulation and toxicity. The physiological symptoms related to the biological effects are also enumerated in Table 4. Habitual khat chewers, who consume repeatedly large doses of the leaves perhaps on a daily basis could therefore be more exposed to the negative biological impacts of khat use in the long term.

Table 5 shows the concentration range of heavy metals and/or trace metals from various khat samples and the provisional tolerable weekly intake (PTWI) in (mg) and recommended daily allowance (RDA) of some heavy metals as provided by WHO and Food Agriculture Organization (FAO) (Tadesse and Kebede 2015; Al Bratty et al. 2019; Woldamanuel 2019). When the concentration of heavy metals does not exceed the recommended PTWI and RDA values, then no adverse health problems is reported, although bio-accumulation in the body tissues may eventually be deleterious (Woldamanuel 2019).

High levels of Fe and $\mathrm{Zn}$ can be associated with soils where khat is grown - khat may be grown in soils that are reasonably acidic and to some extent basic with $\mathrm{pH}$ values ranging from 5.6 to approximately 7.3 (Atlabachew et al. 2011). Specifically, for Fe, its high concentration is associated with high amounts of organic matter in the soil and anthropogenic activities (Fenta and Kidanemariam 2015). Accordingly, elevated levels of Fe in khat can cause heart and liver damage (Ashenef et al. 2014). Copper concentrations in khat are influenced by its concentration in the soil (Woldamanuel 2019). Previous studies reported emissions of $\mathrm{Pb}$ from vehicle exhaust, emission of $\mathrm{Cd}$ from incineration practices and application of manure and fertilizers in another major source of $\mathrm{Pb}$ and $\mathrm{Cd}$ hence their significantly high levels in Khat products

Table 5 The levels of heavy metals in various khat samples cultivated in selected countries and the WHO/FAO recommended heavy metal permissible limits

\begin{tabular}{|c|c|c|c|c|}
\hline Heavy metal & $\begin{array}{l}\text { Concentration range of heavy } \\
\text { metal in khat samples }\end{array}$ & Country of study & $\begin{array}{l}\text { WHO/FAO } \\
\text { recommended values }\end{array}$ & References \\
\hline \multirow[t]{3}{*}{$\mathrm{Pb}$} & $0.18-0.87 \mathrm{mg} / \mathrm{kg}$ & Jazan, Saudi Arabia & 1.75 mg PTWl & Al Bratty et al. (2019) \\
\hline & $0.18-0.87 \mathrm{mg} / \mathrm{kg}$ & Ethiopia & 1.75 mg PTWI & Woldamanuel (2019) \\
\hline & $0.97 \pm 0.37 \mu \mathrm{g} / \mathrm{g}$ & Ethiopia & $214 \mu \mathrm{g}$ RA & Ashenef et al. (2014) \\
\hline \multirow[t]{4}{*}{$\mathrm{Cd}$} & ND & Ethiopia & $2 \mu \mathrm{g} / \mathrm{g} P \mathrm{~L}$ & Tadesse and Kebede (2015) \\
\hline & $0.00-0.08 \mathrm{mg} / \mathrm{kg}$ & Jazan, Saudi Arabia & 0.49 mg PTWl & Al Bratty et al. (2019) \\
\hline & $0.15 \pm 0.90 \mu \mathrm{g} / \mathrm{g}$ & Ethiopia & 0.49 mg PTWl & Woldamanuel (2019) \\
\hline & $0.87 \pm 1.44 \mu \mathrm{g} / \mathrm{g}$ & Ethiopia & $60 \mu \mathrm{g}$ RDA & Ashenef et al. (2014) \\
\hline \multirow[t]{3}{*}{$\mathrm{Mn}$} & ND & Ethiopia & $0.02 \mu \mathrm{g} / \mathrm{g} \mathrm{PL}$ & Tadesse and Kebede (2015) \\
\hline & $339.63-1284.43 \mathrm{mg} / \mathrm{kg}$ & Jazan, Saudi Arabia & 6.68 mg PTWI & Al Bratty et al. (2019) \\
\hline & $11.64 \pm 4.28 \mu \mathrm{g} / \mathrm{g}$ & Ethiopia & $2000 \mu \mathrm{g}$ RDA & Ashenef et al. (2014) \\
\hline $\mathrm{Co}$ & $0.51-1.73 \mathrm{mg} / \mathrm{kg}$ & Jazan, Saudi Arabia & 1.33 mg PTWI & Al Bratty et al. (2019) \\
\hline \multirow[t]{2}{*}{$\mathrm{Cu}$} & $254.60-1757.37 \mathrm{mg} / \mathrm{kg}$ & Jazan, Saudi Arabia & 245 mg PTWl & Al Bratty et al. (2019) \\
\hline & $0.10-41.80 \mu \mathrm{g} / \mathrm{g}$ & Ethiopia & 245 mg PTWI & Woldamanuel (2019) \\
\hline \multirow[t]{5}{*}{$\mathrm{Zn}$} & NG & Ethiopia & $10 \mu \mathrm{g} / \mathrm{g} \mathrm{PL}$ & Tadesse and Kebede, (2015) \\
\hline & $7.17 \pm 1.11 \mu \mathrm{g}$ & Ethiopia & $3000 \mu \mathrm{g}$ RDA & Ashenef et al. (2014) \\
\hline & $351.95-1240.93 \mathrm{mg} / \mathrm{kg}$ & Jazan, Saudi Arabia & 490 mg PTWI & Al Bratty et al. (2019) \\
\hline & $25.15-73.95 \mu \mathrm{g} / \mathrm{g}$ & Ethiopia & 490 mg PTWI & Woldamanuel (2019) \\
\hline & $40.98 \pm 20.2 \mu \mathrm{g}$ & Ethiopia & $60,000 \mu \mathrm{g} R \mathrm{RD}$ & Ashenef et al. (2014) \\
\hline \multirow[t]{3}{*}{$\mathrm{Fe}$} & $6.80-8.96 \mu \mathrm{g} / \mathrm{g}$ & Ethiopia & $50 \mu \mathrm{g} / \mathrm{g} \mathrm{PL}$ & Tadesse and Kebede (2015) \\
\hline & $529.13 \pm 350.03 \mu \mathrm{g}$ & Ethiopia & $10,000 \mu \mathrm{g}$ RDA & Ashenef et al. (2014) \\
\hline & $33.87-59.044 \mu \mathrm{g} / \mathrm{g}$ & Ethiopia & $20 \mu \mathrm{g} / \mathrm{g} \mathrm{PL}$ & Tadesse and Kebede (2015) \\
\hline
\end{tabular}


(Ashenef et al. 2014; Woldamanuel 2019). Exposure to Cd leads to liver cirrhosis over time (Kang et al. 2013). The recommended daily allowance (RDA) and PTWI recommendable levels given by $\mathrm{WHO} / \mathrm{FAO}$ for metals do not pose a health risk when consumption of a maximum amount of preferably $100 \mathrm{~g} /$ day of fresh khat is not exceeded, otherwise, if this threshold is exceeded, it may result in adverse health consequences (Tadesse and Kebede 2015; Woldamanuel 2019). Accordingly, chewing of khat is a precursor for heavy metal poisoning (Tadesse and Kebede 2015). A summary of the concentration of various heavy metals detected in khat and their permissible limits is presented in Table 5 .

Detection of $\mathrm{Pb}$ and $\mathrm{Cd}$ heavy metals usually introduced naturally or anthropogenically to enhance the growth of Khat has a potential for severe health consequences (Ashenef et al. 2014). Cadmium metal for instance, is hazardous and is capable of causing chronic toxicity in the body. While in the body, Cd binds itself to metallothioneins to form cadmium- metallothionein complex that is transported to all body organs thus precipitating serious cell injury and damage (Suhartono et al. 2014). Cadmium is largely deposited in the liver, lungs, kidneys and pancreas (Suhartono et al. 2014) and has been proposed to enter the human and animal biological structures through dermal contact, inhalation and ingestion (Wu et al. 2016).
Children should be discouraged from khat use because the detection of $\mathrm{Pb}$ in khat has adverse effects in their mental health and growth (Woldamanuel 2019). Agricultural practices such as the use of fertilizers, chemical composition of the soil, climatic conditions and the location where khat is grown determines the heavy metal content in khat products especially the leaves (cf. Table 5) (Tadesse and Kebede 2015). Nonetheless, most of the health problems suffered by the khat chewing community are related to natural alkaloids in khat (cathinone and cathine) which are strongly linked to synthetic pesticides sprayed on khat trees specifically on chewable khat leaves (Nigatu and Libsu 2019). The major alkaloids of khat are presented in Fig. 2, vide supra.

\section{Pesticides commonly used in khat farms and their health concerns}

Pesticides are chemicals commonly introduced in farms in order to control disease infestations and target pests ( Richardson et al. 2019; Weyesa 2021), in addition to being used as growth regulators (Regassa and Regassa 2018). They can be designed in form of pellets, dusts and liquids (Weyesa 2021). Moreover, they can be classified depending on the target pests including herbicides (weeds), insecticides (insects), rodenticides (rodents) and fungicides (molds and fungi) (Meftaul et al. 2020). Besides, classification is also based on their methods

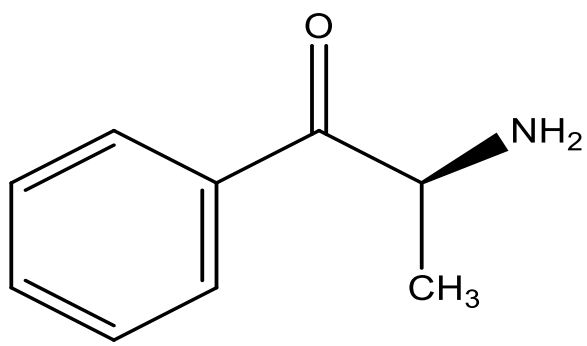

cathinone

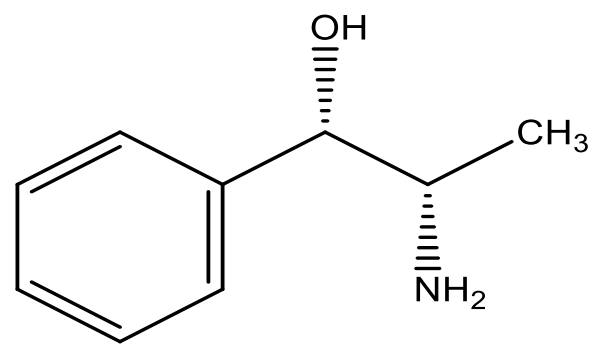

cathine

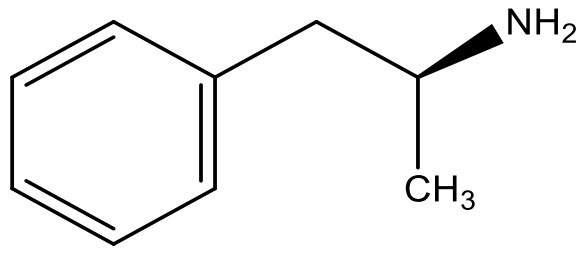

amphetamine

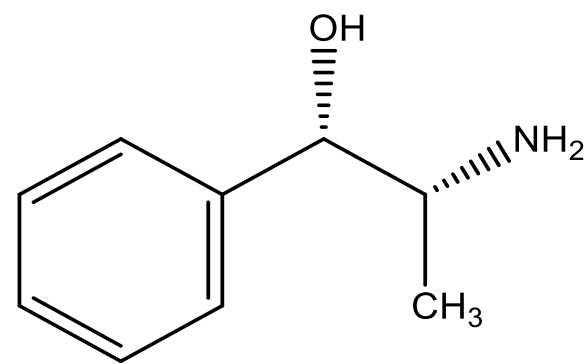

norephedrine

Fig. 2 Major chemical structures of psychostimulants in Khat plant—Adapted from Nigatu and Libsu (2019) 
of application and chemical identity (Richardson et al. 2019). Pesticides act as the backbone of agriculture especially in highly mechanized farms (Richardson et al. 2019). In this regard, they are used to improve the quality, yield and quantity of production hence the reason for their widespread use (Regassa and Regassa 2018). Their use and production is regulated by the regulatory agencies and government authorities globally (Hassan et al. 2016; Meftaul et al. 2020) although their contamination effects are significantly high across the world (Meftaul et al. 2020). Because of their high toxicity levels, they can harm other non-target insects such as honeybees, and birds thus resulting in environmental health pollution challenges (Regassa and Regassa 2018). Vulnerability of khat plant to pest damage and attack is the most important reason why khat cultivators have shifted attention to pesticide use in khat farms with the aim of boosting returns (Regassa and Regassa 2018), and prevent loss of farm produce (Weyesa 2021).

Previous studies have found that khat farmers use chemicals such as dichlorodiphenyltrichloroethane (DDT), wuhagare, sevin, malathion, actelic (Ademe et al.
2020; Regassa and Regassa 2018), diazinon and organophosphate pesticides (Ademe et al. 2020) to deter pests from attacking khat plants. Notably, DDT pesticide is preferred among majority of khat growers since it also increases khat production (Regassa and Regassa 2018; Weyesa 2021). Affordability and effectiveness of a pesticide gives credit to wide spread use despite its illegal status and associated environmental concerns (Regassa and Regassa 2018). Studies conducted in Ethiopia confirmed the presence of diazinon and DDT pesticides in khat and their association with death (Ademe et al. 2020). Malathion, diazinon, DDT and actelic pesticides as shown in Fig. 3 are commonly sprayed on crops to control pest attack (Ademe et al. 2020; Weyesa 2021). Studies on experimental animal models have demonstrated that malathion causes chromosomal abnormalities and micronuclei damage (Daba et al. 2011; Hassan et al. 2016). Voluntary negligence of application procedures of these pesticides can lead to pesticides poisoning and associated fatalities-with khat farmers being the immediate casualties (Regassa and Regassa 2018).

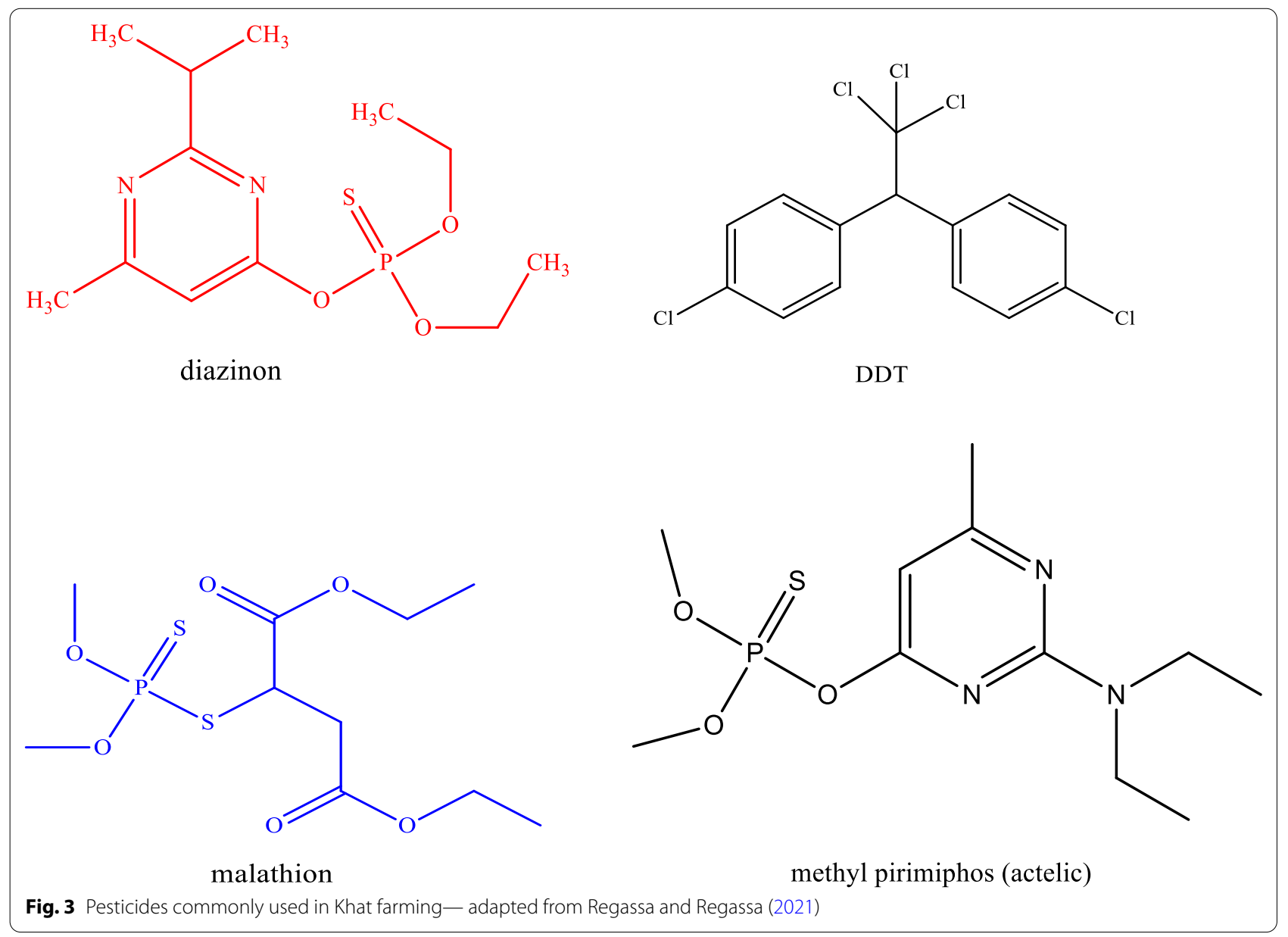


Some of these pesticides are carcinogenic (Weyesa 2021) and upon chronic exposure may lead to genotoxic effects, cases of endocrine disturbances (Swaddiwudhipong et al. 2010; Hassan et al. 2016), and hinder proper functioning of the immune system (Karunamoorthi et al. 2012). Additionally, pesticide application and diseases such as liver diseases, digestive system disorders and respiratory problems are positively correlated (Regassa and Regassa 2018). Besides, there have been immediate cases of headache, eye irritations and increased heart beat during pesticide spray in the absence of protective gear (Weyesa 2021). Moreover, skin irritations, dizziness, depression and breathing difficulties have been reported in literature (Derso and Dagnew 2019). Consumers of khat reported stomach irritations upon chewing khat that has been contaminated with pesticides (Regassa and Regassa 2018).

Table 6 gives a brief overview of the potential health concerns associated with selected organic agrochemical pesticides commonly used in khat farming. Clinical studies have also shown that organic compounds produced naturally by khat can penetrate the gut system and the human blood plasma after chewing khat leaves (Widler et al. 1994; Halket et al. 1995). Organic pesticides can potentially persist through bioa-ccumulation mechanisms and become deposited as residues in the human blood system upon prolonged khat consumption. Previous studies have shown detectable levels of organochlorine pesticide residues of benzene hexachloride in human blood(Subramaniam and Solomon 2006).

Benzene hexachloride (BHC) and DDE can therefore be found in human blood as a result of direct and indirect exposure (Subramaniam and Solomon 2006). Other studies have also detected levels of a variety of pesticide residues including aldrin, DDT, BHC, and diazinon in khat leaves from selected Khat-growing farmlands (Adamu et al. 2020). This means that excessive levels of intake of cultivated khat can potentially lead to accumulation of the pesticide residues in the human internal organs and perhaps disrupt the normal biochemistry and metabolic functions of man. This can contribute to negative health

Table 6 Potential health effects associated with organophosphate and organochlorine pesticides applied in khat farming

\begin{tabular}{|c|c|c|c|c|c|}
\hline $\begin{array}{l}\text { Classification of } \\
\text { pesticide }\end{array}$ & Trade name & Molecular formula & $\begin{array}{l}\text { Name of the organic } \\
\text { active ingredient }\end{array}$ & $\begin{array}{l}\text { Potential health effects } \\
\text { and hazards linked to } \\
\text { high levels of exposure }\end{array}$ & References \\
\hline \multirow[t]{4}{*}{ Organophosphates } & Actellic & $\mathrm{C}_{11} \mathrm{H}_{20} \mathrm{~N}_{3} \mathrm{O}_{3} \mathrm{PS}$ & $\begin{array}{l}\text { Primiphos-methyl or } \\
\text { O-[2-(Diethylamino)- } \\
\text { 6-methylpyrimidin- } \\
\text { 4-yl] O,O-diethyl phospho- } \\
\text { rothioate }\end{array}$ & Cholinesterase inhibitor & Syngenta (2013) \\
\hline & & & & Eye and skin irritant & WHO (2013) \\
\hline & Malathion & $\mathrm{C}_{10} \mathrm{H}_{19} \mathrm{O}_{6} \mathrm{PS}_{2}$ & $\begin{array}{l}\text { O,O-dimethyl dithiophos- } \\
\text { phate of diethyl mercapto- } \\
\text { succinate }\end{array}$ & $\begin{array}{l}\text { Cholinesterase inhibitor } \\
\text { Dermal toxicity } \\
\text { Reproductive and } \\
\text { developmental effects in } \\
\text { mammals } \\
\text { Endocrine disruption }\end{array}$ & $\begin{array}{l}\text { Olovi et al. (2013) } \\
\text { Cabello et al. (2003) } \\
\text { Tchounwou et al. (2015) }\end{array}$ \\
\hline & Diazinon & $\mathrm{C}_{12} \mathrm{H}_{21} \mathrm{~N}_{2} \mathrm{O}_{3} \mathrm{PS}$ & $\begin{array}{l}\text { O,O-Diethyl O-[4-methyl- } \\
\text { 6-(propan-2-yl)pyrimidin- } \\
\text { 2-yl] phosphorothioate }\end{array}$ & Endocrine disruption & $\begin{array}{l}\text { Nicolopoulou-Stamati P } \\
\text { et al. (2016) }\end{array}$ \\
\hline \multirow[t]{4}{*}{ Organochlorines } & DDT & $\mathrm{C}_{14} \mathrm{H}_{9} \mathrm{Cl}_{5}$ & $\begin{array}{l}\text { Dichlorodiphenyltrichlo- } \\
\text { roethane }\end{array}$ & $\begin{array}{l}\text { Possible carcinogen } \\
\text { Endocrine disruption } \\
\text { Poor embryonic develop- } \\
\text { ment }\end{array}$ & $\begin{array}{l}\text { Wallace (2015) } \\
\text { Garabrant et al. (1992) } \\
\text { Nicolopoulou-Stamati et al. } \\
\text { (2016) } \\
\text { Tiemann (2008) }\end{array}$ \\
\hline & DDE & $\mathrm{C}_{14} \mathrm{H}_{8} \mathrm{Cl}_{4}$ & $\begin{array}{l}\text { Dichlorodiphenyldichloro- } \\
\text { ethylene }\end{array}$ & $\begin{array}{l}\text { Possible carcinogen } \\
\text { Neurodevelopment effect } \\
\text { in children } \\
\text { Endocrine disruption }\end{array}$ & $\begin{array}{l}\text { Breast Cancer Fund Organi- } \\
\text { zation (2004) } \\
\text { Nicolopoulou-Stamati et al. } \\
\text { (2016) } \\
\text { Eskenazi et al. (2006) }\end{array}$ \\
\hline & Aldrin & $\mathrm{C}_{12} \mathrm{H}_{8} \mathrm{Cl}_{6}$ & $\begin{array}{l}\text { Hexachlorohexahy- } \\
\text { drodimethano-naphtha- } \\
\text { lene }\end{array}$ & Endocrine disruption & Lemaire et al. (2006) \\
\hline & $\mathrm{BHC}$ & $\mathrm{C}_{6} \mathrm{H}_{6} \mathrm{Cl}_{6}$ & Benzene hexachloride & Endocrine disruption & $\begin{array}{l}\text { Nicolopoulou-Stamati et al. } \\
\text { (2016) }\end{array}$ \\
\hline
\end{tabular}




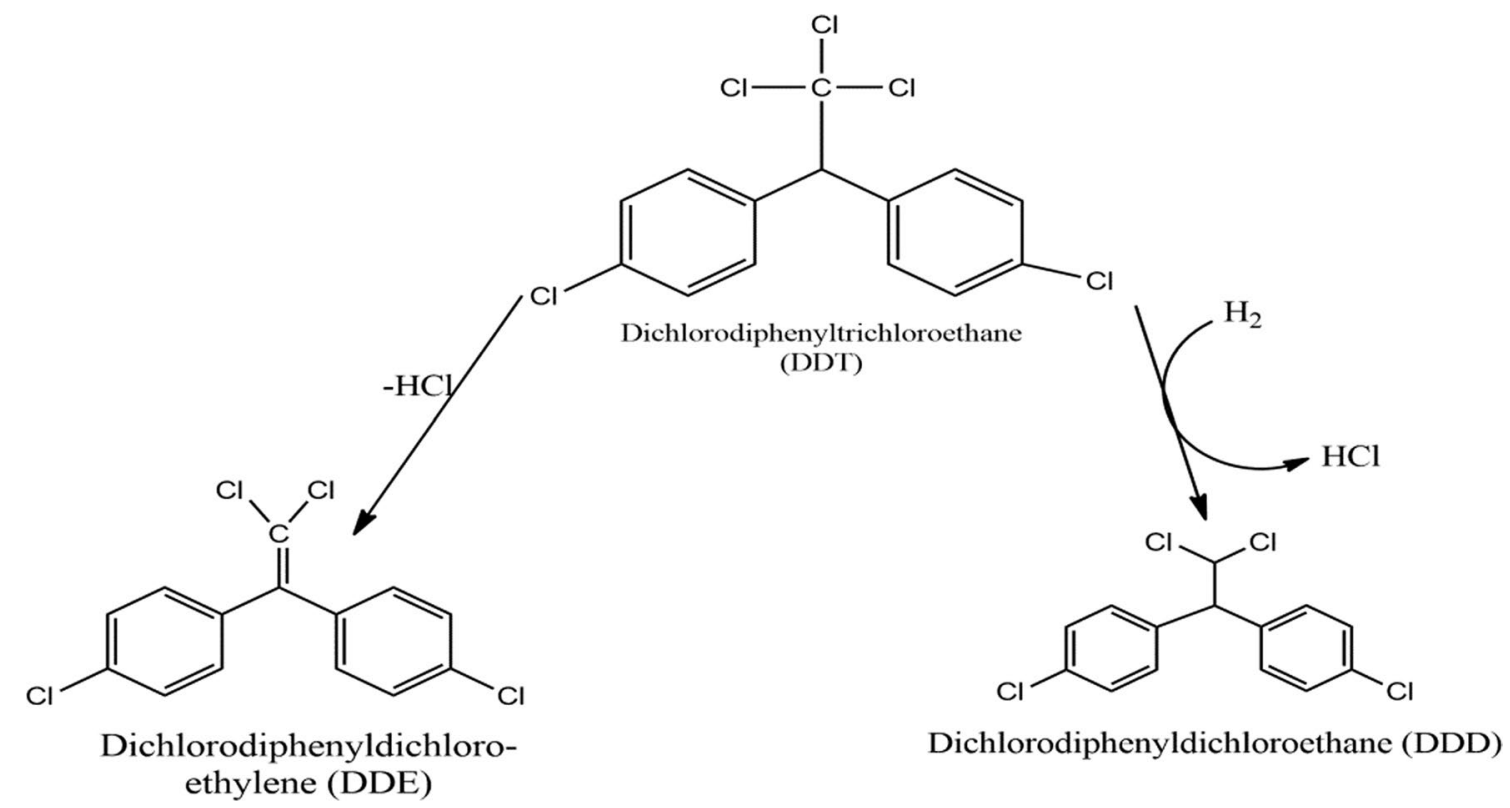

Scheme 1 Proposed mechanistic degradation of DDT in the environment to DDE and DDT— Adapted from Fossi et al. (2014)

effects when they are ingested above the threshold limits as documented by WHO (2013).

DDT is a man-made chemical developed in the $1940 \mathrm{~s}$ specifically for use as an insecticide (Kaoud 2015). Technical-grade DDT may also contain DDE (dichlorodiphenyldichloro-ethylene) and DDD (dichlorodiphenyldichloroethane) (Scheme 1) which are breakdown products of DDT (Fossi et al. 2014). DDT is a long-lasting, toxic chemical which builds up in the tissues of living organisms (Kaoud 2015). Under the Stockholm Convention, it is banned worldwide for use in agriculture, but it is still being used in developing countries for particularly in crop production (Ali et al. 2014). In countries where DDT is still in use, most release is due to its use as an insecticide (Ali et al. 2014). It can enter the atmosphere by evaporation and can contaminate surface water from soil run-off (McKnight et al. 2015). DDT may also escape into the environment as a result of accidental discharges during use or during its manufacture (Fossi et al. 2014). The persistence of DDT and its breakdown products has contributed to their bioaccumulation and bio-magnification (increasing concentration of a chemical in organisms higher up the food chain) in the environment (Vorkamp and Rigét 2014). Besides its breakdown products, DDT is ubiquitous in food and the environment (Kaoud 2015). Exposure to DDT has been linked to breast cancer, reproductive difficulties, liver damage and delays in neurodevelopment during early childhood (Ali et al. 2014). Therefore contamination of khat shoots of leaves by DDT and its by-products can be detrimental to human health.
The non-biodegradability nature DDT makes it a precursor for majority of health diseases because of its massive use in pest control despite having been banned in developed countries (Regassa and Regassa 2018). Organochlorine pesticides such as DDT cause cancers (esophageal and oral) among khat chewers (Daba et al. 2011; Woldetsadik et al. 2021). Notably, DDT pesticide is banned in most developed countries such as US and Europe because of its adverse health effects (Meftaul et al. 2020) such as stillbirth and endocrine disorders (Karunamoorthi et al. 2012). Among other countries that have also banned the use of DDT for agricultural use include Ethiopia and partly Kenya (Adamu et al. 2020). Pesticide residues on chewable khat leaves and young shoots are responsible for pesticide poisoning and eventually death (Ademe et al. 2020). Therefore, proper management practices on pesticide application procedures need be adopted in order to avoid potential pesticide poisoning, possible fatalities and environmental health pollution (Derso and Dagnew 2019). Moreover, allowable limits set by regulatory bodies need be observed and adhered to in order to mitigate the hazardous impacts of these pesticides. For instance, under the European Union (EU), regulation set for both diazinon and DDT pesticides is that the maximum residue level (MRL) is $10 \mu \mathrm{g} /$ $\mathrm{kg}$ particularly for fruits and vegetables (Daba et al. 2011; Adamu et al. 2020). 


\section{The toxicology of khat use}

Regular khat use particularly chewing has been associated with human medical problems such as diminishing libido, cancer cases, depression, dental carries, liver damage and hypertension (Tarboush et al. 2019; Belayneh and Mekuriaw 2019; Al Bratty et al. 2019; Tessema and Zeleke 2020). It is believed that psychoactive ingredients in khat-cathine and cathinone are confirmed precursors for cancer (oral and esophageal) among regular khat chewers (Omare 2020; Yadeta et al. 2020). An increase in cathinone concentrations in plasma leads to increase in blood pressure (Geta et al. 2019). It is also important to note that the presence of high levels of toxic metal ions in Khat are hazardous and can potentially damage major body organs such as the liver and kidneys (Al Bratty et al. 2019). Furthermore, consumption of unclean khat leaves containing residual pesticides causes cancer and genotoxicity (Atnafie et al. 2021). The liver is a vital organ responsible for detoxifications functions and metabolic activities (Djurasevic et al. 2019). Due to its central role in the body system, it is highly vulnerable to toxic effects of khat use (Al-Mehdar et al. 2012). Chewing of khat has a close association with severe liver damage, (Kassim et al. 2015; Al-Rajab et al. 2016; Mahamoud et al. 2016; Orlien et al. 2018) and fibrosis (Ademe et al. 2020). Additionally, the presence of tannic acid in khat is responsible for hepatic toxicity (Jayed and Al-Huthi 2016). Fibrosis results in some cases due high $\mathrm{Cd}$ accumulation in the liver after exposure to regular low doses (Baba et al. 2013). Unfortunately, the liver may not recover after khat use cessation (Makeen et al. 2021) which may lead to liver transplant (Heidelbaugh and Bruderly 2006; Ademe et al. 2020), in extreme cases. It medically established that liver cirrhosis is a silent disease, with most patients remaining asymptomatic until decompensation occurs (Heidelbaugh and Bruderly 2006).

The liver injuries manifest themselves because of possible metabolization of toxic khat components including heavy metals and pesticides (Heidelbaugh and Bruderly 2006). This may trigger psychological effects such as insomnia and depression (Heidelbaugh and Bruderly 2006). Research conducted on rodents experimented on diet containing khat products showed high liver enzymes and histology necro-inflammatory change, suggesting that khat products cause liver damage (Orlien et al. 2018). Arguably, the liver plays a critical role in the maintenance and balance of $\mathrm{Fe}$ and $\mathrm{Cu}$ in the body, which mainly enhance lipid peroxidation (Djurasevic et al. 2019). However, absorption of $\mathrm{Cu}$ and $\mathrm{Fe}$ in excess (Djurasevic et al. 2019) may result in high bio-accumulation levels that are damaging to the liver (Ashenef et al. 2014). Similarly, Cd is an element which is highly toxic with long biological half-life ranging from approximately 6-39 years and is capable of causing serious health problems including nervous breakdown, liver and kidney failure (Egger et al. 2019). Cadmium is a well-established carcinogen known to lower bone mineral density at relatively high exposure (Egger et al. 2019). Cadmium enters the system of a living organism through gastrointestinal tract and the respiratory airway with exposure period and dosage key to intoxication of the liver (Djurasevic et al. 2019). In humans, epidemiological studies are used to show association of liver dysfunction and exposure to cadmium metal (Kang et al. 2013). It reduces Fe concentration in the liver hence reducing enzymatic activity and causes zero protein regulation (Djurasevic et al. 2019). Moreover, $\mathrm{Cd}$ has the potential of damaging the adrenals, causes cell death and is a well-known precursor for kidney impairment (Egger et al. 2019). Unregulated use of illegal pesticides on khat such as 1,1,1-trichloro-2,2-bis [4-chlorophenyl] ethane (DDT), a carcinogenic chemical cause severe liver damages among khat users (Weyesa 2021). Liver cirrhosis is a disease that can lead to death because of its action to impede liver functions (Tsochatzis et al. 2014). Injury to the liver parenchyma attributed to an inflow of acute or chronic inflammatory cells is a precursor for hepatitis-a deadly disease (Adamu et al. 2019).

\section{Khat as a precursor for cancer}

Herein, we discuss two types of cancer-Oral and esophageal cancers that have proved to be fatal mainly in developing countries such as Ethiopia, Somalia, Djibouti and Kenya (Ram et al. 2011; Yang and Chen 2020). Oral cancer is caused by excessive consumption of alcohol and smoking of cigarettes notwithstanding khat use (Warnakulasuriya 2009). It has also been confirmed that khat chewing is associated with esophagitis, periodontitis and oral cancer (Yang and Chen 2020). Oral cancer is among the common cancers globally which affect the lower side of the mouth, tongue, the cheek (Warnakulasuriya 2009; Ram et al. 2011) and buccal mucosa (Ahmed et al. 2011). Most of these are cell carcinomas (Morse et al. 2007). Cancer is significantly associated with dietary deficiencies, viral and dental factors (Ram et al. 2011). Other cancers are significantly associated with parasitic diseases, bacteria and trematode infestations (De Flora and Bonanni 2011). Chewing of khat has been closely associated with oral cancer mainly among khat chewers (Lu et al. 2017; Nigatu and Libsu 2019). The regular chewing side of the mouth of a khat chewer may develop changes such as keratotic white lesions (Schmidt-Westhausen et al. 2014), oral epithelial dysplasia (OED), irritation of the esophagus and white lesions in the mouth that represent a reactive process or the development of cancer (Leon et al. 2017). Oral epithelial dysplasia (OED) is characterized by cellular changes indicative of the 
Table 7 Selected demographic characteristics of khat users, the related physiological symptoms of cancers and the factors actuating consumption of khat

\begin{tabular}{|c|c|c|c|c|c|c|c|}
\hline \multirow[t]{2}{*}{ Type of study } & \multirow[t]{2}{*}{$\begin{array}{l}\text { Country of } \\
\text { study }\end{array}$} & \multirow[t]{2}{*}{ Age } & \multicolumn{2}{|c|}{$\begin{array}{l}\text { Descriptive statistics related to } \\
\text { cancer cases }\end{array}$} & \multirow{2}{*}{$\begin{array}{l}\text { Physiological } \\
\text { abnormalities } \\
\text { associated } \\
\text { with cancer } \\
\text { development }\end{array}$} & \multirow{2}{*}{$\begin{array}{l}\text { Factors that } \\
\text { actuate the } \\
\text { consumption } \\
\text { of Khat among } \\
\text { the users }\end{array}$} & \multirow[t]{2}{*}{ References } \\
\hline & & & $\begin{array}{l}\text { Recorded } \\
\text { number of } \\
\text { participants }\end{array}$ & $\begin{array}{l}\text { Khat } \\
\text { consumers } \\
\text { in terms of } \\
\text { percentages } \\
\text { (\%) of the } \\
\text { respective } \\
\text { populations }\end{array}$ & & & \\
\hline $\begin{array}{l}\text { Administered } \\
\text { interviews }\end{array}$ & Ethiopia & $<18$ years & $N P^{*}$ & $N P^{*}$ & Mouth sores & $\begin{array}{l}\text { Peer pressure, } \\
\text { Religious beliefs, } \\
\text { and Social influ- } \\
\text { ences }\end{array}$ & Sinba (2017) \\
\hline $\begin{array}{l}\text { Cross-sectional } \\
\text { hospital study }\end{array}$ & Yemen & $20-65$ years & 82 & $75.20 \%$ & $\begin{array}{l}\text { White lesions on } \\
\text { oral mucosa }\end{array}$ & Social influences & $\begin{array}{l}\text { Schmidt-West- } \\
\text { hausen et al. } \\
\text { (2014) }\end{array}$ \\
\hline $\begin{array}{l}\text { Population } \\
\text { survey }\end{array}$ & Israel & $<30$ years & 39 & $83 \%$ & $\begin{array}{l}\text { White lesions on } \\
\text { skin sections }\end{array}$ & $\begin{array}{l}\text { Global spread } \\
\text { of Khat usage, } \\
\text { Smoking }\end{array}$ & Gorsky et al. (2004) \\
\hline $\begin{array}{l}\text { Pilot case-con- } \\
\text { trol study }\end{array}$ & Ethiopia & $<18$ years & $73 C^{*}$ & $35.40 \%$ & $\mathrm{CC}^{*}$ & $\begin{array}{l}\text { Traditions, } \\
\text { culture and } \\
\text { religious beliefs }\end{array}$ & Leon et al. (2017) \\
\hline $\begin{array}{l}\text { Cross-sectional } \\
\text { study }\end{array}$ & Ethiopia & $\begin{array}{l}31.86 \text { years } \\
\text { (Mean Age) }\end{array}$ & $N P^{*}$ & $N P^{*}$ & Lesions & $\begin{array}{l}\text { Leisure activities, } \\
\text { family history } \\
\text { of tobacco use } \\
\text { peer pressure }\end{array}$ & Molla et al. (2017) \\
\hline $\begin{array}{l}\text { Case-control } \\
\text { study }\end{array}$ & Yemen & $\begin{array}{l}56.95 \text { years } \\
\text { (Mean Age) }\end{array}$ & $N P^{*}$ & $N P^{*}$ & $\begin{array}{l}\text { Lesions, lymph } \\
\text { node, mucosal } \\
\text { burns }\end{array}$ & $\begin{array}{l}\text { Smoking and } \\
\text { experimental } \\
\text { Khat chewing }\end{array}$ & Nasher et al. (2014) \\
\hline $\begin{array}{l}\text { Cross-sectional } \\
\text { population } \\
\text { based study }\end{array}$ & Ethiopia & $15-69$ years & $N P^{*}$ & $N P^{*}$ & $N P^{*}$ & $\begin{array}{l}\text { Khat chewing } \\
\text { that accompany } \\
\text { heavy alcohol } \\
\text { consumption }\end{array}$ & Defar et al. (2017) \\
\hline $\begin{array}{l}\text { Descriptive } \\
\text { study }\end{array}$ & Kenya & Adults & 51 & 75 & ${ }^{*} \mathrm{NP}$ & $\begin{array}{l}\text { Mouth sores, } \\
\text { dental carries, } \\
\text { alcohol con- } \\
\text { sumption }\end{array}$ & $\begin{array}{l}\text { Njuguna et al. } \\
\text { (2013) }\end{array}$ \\
\hline
\end{tabular}

${ }^{*} N P$ not provided, $C C$ cancer cases

development of malignancy which can later be oral carcinogenesis (Morse et al. 2007).

Table 7 presents some selected case studies conducted in selected khat growing regions which include countries in the horn of Africa and in Arabian regions. These studies have shown a link between the consumption of khat and development of cancer related physiological symptoms. In one pilot case study in Ethiopia, more than a third of the patients reporting various forms of cancer were found to be actually younger khat consumers (Leon et al. 2017). The studies have also revealed and documented some of the factors that actuate and perpetuate the consumption of khat among its consumers. Some of the key factors include peer pressure, social influences, smoking, religion, cultural beliefs and traditions which continue to contribute to the rise in khat consumption and possible abuse of the recreational psychostimulant herbal drug.

The elevated levels of khat toxins and the precancerous keratotic white lesion development in the cheek where khat boluses are placed during chewing of khat are progenitors for oral cancer (Yarom et al. 2010; Kassab and Al Moustafa 2017). The major organic chemicals; cathine and cathinone induce precancerous chromosomal changes and death of cells through apoptosis (Ahmed et al. 2011). Besides, illegal pesticide remnants on khat leaves and products are the primary cause of cancer for chewers of khat who preferentially consume unclean raw fresh leaves (Karunamoorthi et al. 2012; Weyesa 2021). Excessive use of these pesticides can also cause genotoxicity and ultimately increase the chances for the development of diabetes mellitus (Atnafie et al. 2021). Similarly, application of toxic organochlorine pesticides such as 
DDT increases chances of cancer (Al-Akwa et al. 2009; Regassa et al. 2020). DDT has a slow transformation, strong lipophilic and high affinity for animal and human tissues thus causing more harm (Regassa et al. 2020). Oral cancer is responsible for malignancies of the oropharynx and the oral cavity-reports in 2012 estimated nearly 300,000 cases of cancer and 145,000 fatalities globally with survival rate of approximately $60 \%$ (Kassab and Al Moustafa 2017). Other cancers such as esophageal cancer may result after chronic irritations of the esophagus associated with khat extract during swallowing (Yadeta et al. 2020).

Regular chewing of khat is associated with the development of white lesions on the oral mucosa as a result of chemical effects (Gorsky et al. 2004; Schmidt-Westhausen et al. 2014). The relationship between khat chewing and oral malignancy is highly suspected despite some studies nullifying this association (Gorsky et al. 2004). Nonetheless, recent studies portray etiological role of this association majorly with esophageal and oral cancers (Leon et al. 2017). Chewing of khat shoots sprayed with DDT and diazinon pesticides have a higher chance to cause cancer cases in human since these pesticides are ranked among the most toxic organics in the environment (Leon et al. 2017). Due to many carcinogenic chemicals in tobacco, it is clear that tobacco smoking causes ailments including cancer (Molla et al. 2017). Remarkably, the percentage of cases observed from khat users is high (Table 7), with studies suggesting the carcinogenicity of khat extract among khat users (Nasher et al. 2014; Defar et al. 2017). It has been reported in literature that over $50 \%$ of households in Djibouti, approximately $70 \%$ Yemenis, and about 30\% of Ethiopians consume khat (Desta and Ataklti 2015; Tadesse and Kebede 2015). With these statistics, it is evident that possible consumption of khat contaminated with farming chemicals and heavy metals is a concern that needs to be investigated further. Already, WHO has reported that in Yemen for instance, $30-50 \%$ of female adults use khat regularly (Naji et al. 2015) - a worrying observation.

\section{Hypertension and khat use}

Hypertension is a medical condition that develops when blood flows in the artery walls at a high pressure-diastolic blood pressure equal or greater than $90 \mathrm{mmHg}$ and/or a systolic blood pressure (BP) equal or greater than $140 \mathrm{mmHg}$ (Niriayo et al. 2019; Chuka et al. 2020; Abdissa and Kene 2020). This ultimately results in long term health complications (Haye and Tolera Agama 2020), body disabilities (Huang et al. 2021) and sometimes in premature death (Kassa and Woldesemayat 2019; Badego et al. 2020).
Hypertension is currently a health concern worldwide (Niriayo et al. 2019) mainly affecting population of developing countries such as Ethiopia (Kebede et al. 2020) with cases expected to be higher by the year 2025 (Ibrahim and Damasceno 2012). It is estimated that by the year 2025, three out of four people ( $75 \%$ of total population) will be living with high blood pressure conditions (Huang et al. 2021). Hypertension may also result in heart and damage to the blood vessels (Tessema and Zeleke 2020). Notably, it is a primary cause for cardiovascular diseases (Miller et al. 2010; Niriayo et al. 2019) and kidney diseases including renal failures, myocardial infarctions (Oliver-Williams et al. 2018; Kebede et al. 2020), dementia and maternal death during pregnancy (Badego et al. 2020). Cardiovascular problems are generally initiated by the alkaloid chemicals such as cathinone and cathine (Jayed and Al-Huthi 2016).

During the chewing of khat, the heart rate and blood pressure is reported to increase proportionately as chewing process continues resulting in increase in psychoactive component plasma concentrations (Dagne et al. 2010; Geta et al. 2019). In some studies, it is reported that blood pressure can rise nearly 14 times more than that of non khat chewers (Birhane and Birhane 2014). Table 8 shows a summary of different characteristics and khat chewing processes. The numerous vasoconstrictor activities of the alkaloid cathinone is responsible for the increase in blood pressure (Geta et al. 2019). The psychoactive components in khat also increase the heart rate (Geta et al. 2019). High blood pressure is regarded as a primary cause of worldwide disease burden (Kebede et al. 2020; Haye and Tolera Agama 2020). Globally, about 1 billion people suffer from hypertension with fatalities estimated at 7.1 million annually (Miller et al. 2010). Genetic origin of individual, dietary factors, behavioral aspects (Miller et al. 2010; Geta et al. 2019) and medical disorders contribute to high blood pressure (Ibrahim and Damasceno 2012). Other risk factors of high blood pressure include lack of physical exercise, stress, obesity and regular alcohol use (Geta et al. 2019; Huang et al. 2021). Hypertension is closely associated with possible heart failure and stroke related cases (Oliver-Williams et al. 2018; Geta et al. 2019,). Therefore, it is important that early detection, prevention and sensitization on high blood pressure is treated early (Badego et al. 2020). Besides, WHO has adopted worldwide action plan for mitigating measure aimed at reducing the risk of hypertension through awareness programs (Chuka et al. 2020). Contamination of khat leaves and shoots by heavy metals and farming chemicals such as DDT may exacerbate hypertension, liver damage, cancer and kidney related diseases. 
Table 8 Selected studies on the association between hypertension and khat chewing

\begin{tabular}{|c|c|c|c|c|c|}
\hline Type of study & Region/ Country of study & $\begin{array}{l}\text { Association } \\
\text { with } \\
\text { hypertension }\end{array}$ & $\begin{array}{l}\text { Mean age of } \\
\text { participants }\end{array}$ & $\begin{array}{l}\text { Prevalence rate of } \\
\text { hypertension }\end{array}$ & References \\
\hline Comparative study & Butajira, Ethiopia & Yes & $N P^{*}$ & $\begin{array}{l}\text { Prevalence of } 13.4 \% \text { for khat } \\
\text { chewers while } 10.7 \% \text { for non- } \\
\text { khat chewers }\end{array}$ & Miller et al., (2010) \\
\hline Facility-based cross-sectional & Addis Ababa, Ethiopia & Yes & 41.17 years & $\begin{array}{l}\text { Prevalence was } 14 \% \text { for khat } \\
\text { chewers who were patients in } \\
\text { health centers }\end{array}$ & \\
\hline Cross-sectional based & Ethiopia & Yes & $N P^{*}$ & $\begin{array}{l}\text { No information on prevalence } \\
\text { was provided. Prevalent } \\
\text { conditions include lack of } \\
\text { enough physical exercise, low } \\
\text { salt intake and relatively high } \\
\text { weight }\end{array}$ & Niriayo et al. (2019) \\
\hline $\begin{array}{l}\text { Institution-based cross-sec- } \\
\text { tional based }\end{array}$ & Sidama zone, Ethiopia & Yes & $N P^{*}$ & $\begin{array}{l}\text { Prevalence was } 24.5 \% \text {. Khat } \\
\text { chewing, alcohol consump- } \\
\text { tion, old age and obesity are } \\
\text { prevalent conditions }\end{array}$ & Badego et al. (2020) \\
\hline $\begin{array}{l}\text { Hospital-based cross-sectional } \\
\text { based }\end{array}$ & Ethiopia & Yes & 42.30 years & $\begin{array}{l}\text { Prevalence was } 13.2 \% \text {. Fam- } \\
\text { ily history of hypertension, } \\
\text { overweight, oral contracep- } \\
\text { tive and diabetes mellitus are } \\
\text { prevalent conditions }\end{array}$ & Gudina et al. (2013) \\
\hline Community-based & Gurage zone, Ethiopia & Yes & 34.36 years & $\begin{array}{l}\text { The prevalence was } 17.4 \% \\
\text { for Khat chewers and } 8.7 \% \\
\text { for non-Khat chewers. Age, } \\
\text { gender and alcohol intake are } \\
\text { prevalent conditions }\end{array}$ & Geta et al. (2019) \\
\hline
\end{tabular}

${ }^{*} N P$ not provided

\section{Suggested improvement in khat farming practices}

Widespread use of synthetic pesticides and chemical fertilizers poses health, environmental, and livelihood risks especially to Khat farmers in the Horn of Africa and the Arabian Peninsula (Krueger and Mutyambai 2020). The consequences can magnify across a wider population since khat leaves are transported and consumed largely in western countries such as the United Kingdom (UK), Netherlands and the USA. It is therefore important to practice khat cultivation methods that are free of synthetic insecticides and chemical fertilizers. Organic farming is therefore an appropriate management system that would improve soil health environment and facilitate quality crop production, an ultimately minimizing the bio-accumulation of non-essential metals (heavy metals) and farm chemical residues in crops which are known to have deleterious impacts on human health. Organic farming is defined as a crop production system that largely avoids the use of synthetic fertilizers, growth regulators, pesticides, and animal feed additives (Yuvaraj et al. 2020). Improved farming practices are very important in mitigating environmental issues arising from conventional farming procedures, and this drive can be taken as a very positive direction in the food system (Drimie and Pereira
2016). Organic farming focuses on agricultural practice of the farm as a whole and aims at enhancing biological diversity within the farming system; to augment soil biological activity, maintain long-term soil fertility, return nutrients to the soil, and to promote the healthy use of soil, water and air as well as minimize all forms of pollution such as bio-accumulation of heavy metals and synthetic chemical fertilizers (Udo de Haes and de Snoo 2010). Because organic agriculture has some important benefits and promising characteristics, for example, its positive influence on local biodiversity, and high productivity in some circumstances; it is suitable not only for the production of various crops but also khat farming. This farming technique exhibits many potential benefits such as higher biodiversity and improved soil and water quality per unit area, improved profitability, and higher nutritional value as well as many potential costs including better consumer prices (Seufert et al. 2017).

\section{Conclusions}

On the basis of this review, it can be concluded that regular use of khat is associated with acute and chronic toxicity occasioned by bio-accumulation of toxic trace metals and pesticides in the human biological system. 
This can also be augmented by potent psychoactive alkaloids such as cathinone and cathine, and also due to the presence of highly toxic heavy metals- $\mathrm{Pb}, \mathrm{Cd}, \mathrm{Ni}$ and $\mathrm{Cr}$ absorbed by khat plant during cultivation. It is noted, for instance that $\mathrm{Cd}$ is a chemical element which is highly toxic with long biological half-life and capable of causing serious health problems including nervous breakdown, kidney failure and liver damage. Metal toxicity can lead to numerous disorders and can also initiate oxidative stress induced by free radical formation in the biological system. Heavy metal accumulation to toxicity levels as a result of long term exposure can potentially cause adverse health problems such as liver damage, hypertension and cancer among other health problems. This work has also demonstrated that exposure to malathion can cause chromosomal abnormalities and micronuclei damage in experimental animals and is therefore an health hazard especially when used in khat cultivation. The unregulated use of khat is therefore injurious to the khat consuming community. Accordingly, there is need to advise khat farmers to adopt better agricultural practices that incorporates the use of organic pesticides and organic fertilizers.

\begin{abstract}
Abbreviations
BP: Blood pressure; BHC: Benzene hexachloride; CC: Cancer Cases; DDE: Dichlorodiphenyldichloro-ethylene; DDD: Dichlorodiphenyldichloroethane; DDT: Dichlorodiphenyltrichloroethane; FAO: Food Agriculture Organization; ICP-MS: Inductively coupled plasma-mass spectroscopy technique; NG: Not given; ND: Not detectable; NP: Not provided; OED: Oral epithelial dysplasia; PT: Plant limit; PTWI: Provisional tolerable weekly intake; RDA: Recommended daily allowance; UK: United Kingdom; WHO: World Health Organization; XRF: $X$-ray fluorescence spectroscopy.
\end{abstract}

\section{Acknowledgements}

The authors wish to thank Mr. Korir of Egerton University - Department of Chemistry, for his input in editing the bibliography used in this work.

\section{Authors' contributions}

AMO: Formal analysis and Writing the original draft. JKK: Conceptualization, Methodology, Formal analysis, Writing \& Editing, Validation \& Supervision. JOA: Data curation, Formal analysis; Supervision, Writing - review \& editing. All authors have read and approved the manuscript.

\section{Funding}

The authors are grateful to Egerton University grant \#EU/RE/DVC/072 for facilitating this research.

\section{Availability of data and materials}

Not Applicable.

\section{Declarations}

Ethics approval and consent to participate Not Applicable.

\section{Consent for publication}

This article has the consent of all the authors.

\section{Competing interests}

The authors have no competing interests.
Received: 24 June 2021 Accepted: 6 September 2021

Published online: 22 September 2021

\section{References}

Abdissa D, Kene K (2020) Prevalence and determinants of hypertension among diabetic patients in Jimma University Medical Center, Southwest Ethiopia. Diabetes Metab Syndr Obes Targets Ther 13:2317

Abdinasir HY (2013) Factors influencing khat use among male adults in Kisenyi Rubaga Division of Kampala District; International Health Sciences University. http://dspace.ciu.ac.ug/handle/123456789/207. Accessed 3rd August, 2021

Adamu DB, Muluye T, Gonfa T, Achamo T, Tana T (2020) Determination of pesticide residue in water and khat (Catha edulis) leaves using GCECD. J Appl Chem Environ Protect 4(1):16-27

Ademe BW, Brimer L, Dalsgaard A, Belachew T (2020) Chemical and microbiological hazards of Khat (Catha edulis) from field to chewing in Ethiopia. GSC Biological and Pharmaceutical Sciences 11(01):024-035

Ahmed MS, Yesmin M, Jeb F, Hoque MS, Jamee AR, Salam A (2020) Risk assessment and evaluation of heavy metals concentrations in blood samples of plastic industry workers in Dhaka, Bangladesh. Toxicol Rep 7:1373-1380

Ageely HM (2009) Prevalence of Khat chewing in college and secondary (high) school students of Jazan region, Saudi Arabia. Harm Reduct J 6:1-7

Al-Akwa AA, Shaher M, Al-Akwa S, Aleryani SL (2009) Free radicals are present in human serum of Catha edulis Forsk (Khat) abusers. J Ethnopharmacol 125(3):471-3

Al-Bayaty FH, Ali NAW, Bulgiba AM, Masood M, Hussain SF, Abdulla MA (2011) Tooth mortality in khat and non khat chewer in Sanaa Yemen. Sci Res Essays 6:1039-1045

Alfaifi H, Abdelwahab SI, Mohan S, Taha MME, Syame SM, Shaala LA, Alsanosy R (2017) Catha edulis Forsk (Khat): evaluation of its antidepressant-like activity. Pharmacogn Mag 13:S354

Alissa EM, Ferns GA (2011) Heavy metal poisoning and cardiovascular disease. J Toxicol 2011:870125

Ali U, Syed J, Malik R, Katsoyiannis A, Li J, Zhang G, Jones KC (2014) Organochlorine pesticides (OCPs) in South Asian region: a review. Sci Total Environ 476-477:705-717. https://doi.org/10.1016/j.scitotenv.2013. 12.107

Ali WM, Zubaid M, Al-Motarreb A, Singh R, Al-Shereigi SZ, Shehab A, Rashed W, Al-Sagheer NQ, Saleh AH and Al Suwaidi J (2010) Association of khat chewing with increased risk of stroke and death in patients presenting with acute coronary syndrome. Mayo Clinic Proceedings, pp 974-980

Al-Maweri SA, Warnakulasuriya S, Samran A (2018) Khat (Catha edulis) and its oral health effects: an updated review. J Investig Clin Dent 9:122

Al-Mehdar AA, El-Denshary ES, Addel-wahhab M (2012) Alpha lipoic acid and alpha-tocopherol counteract the oxidative stress and liver damage in rats suZb-chronically treated with khat (Catha edulis) extract. Global J Pharmacol 6(2):94-105

Al-Rajab A, Alhababy A, Alfaifi T (2016) Persistence of imidacloprid, acetamiprid and methomyl in qat leaves. Hell Plant Protect J 9(2):51-59

Al Bratty M, Ahsan W, Alhazmi HA, Attafi IM, Khardali IA, Abdelwahab SI (2019) Determination of trace metal concentrations in different parts of the khat varieties (Catha edulis) using inductively coupled plasma-mass spectroscopy technique and their human exposure assessment. Pharmacogn Mag 15(63):449

Alshagga MA, Mohamed Z, Seyedan A, Ebling FJ, Alshawsh MA (2020) Khat (Catha edulis) upregulates lipolytic genes in white adipose tissue of male obese mice (C57BL/6J). J Ethnopharmacol 262:113

Alrobaian M, Arida H (2019) Assessment of heavy and toxic metals in the blood and hair of Saudi Arabia smokers using modern analytical techniques. Int J Anal Chem 2019:7125210

Anyanwu BO, Ezejiofor AN, Igweze ZN, Orisakwe OE (2018) Heavy metal mixture exposure and effects in developing nations: an update. Toxics 6:65

Atlabachew M, Chandravanshi BS, Redi M (2010a) Concentration levels of essential and non-essential metals in Ethiopian Khat (Catha edulis Forsk). Biol Trace Elem Res 138:316-325 
Attafi IM, Albeishy MY, Oraiby ME, Khardali IA, Shaikhain GA, Fageeh MM (2018) Postmortem Distribution of Cathinone and Cathine in Human Biological Specimens in a Case of Death Associated with Khat Chewing. Arab J Foren Sci Foren Med 1:922-930

Alvi A, Rizwan M, Sunosi RA, Jerah ABA (2014) Does khat chewing increases the risk of Mycobacterium tuberculosis infection by macrophage immune modulation? Med Hypoth 82:667-669

Al-Motarreb A, Baker K, Broadley KJ (2002) Khat: pharmacological and medical aspects and its social use in Yemen. Phytother Res 16:403-413

Ashenef A, Birhanu G, Engidawork E (2014) Levels of essential and toxic metals in Ethiopian khat, (Catha edulis forsk.). Ethiop J Environ Stud Manag 7(3):289-97

Atlabachew M, Chandravanshi BS, Redi M (2010b) Concentration levels of essential and non-essential metals in Ethiopian khat (Catha edulis Forsk). Biol Trace Elem Res 138(1):316-325

Atlabachew M, Chandravanshi BS, Zewge F, Redi M (2011) Fluoride content of Ethiopian khat (Catha edulis Forsk) chewing leaves. Toxicol Environ Chem 93(1):32-43

Atnafie SA, Muluneh NY, Getahun KA, Tsegaw Woredekal A, Khaliw W (2021) Pesticide Residue Analysis of Khat Leaves and Health Risks among Khat Chewers in the Amhara Region, Northwestern Ethiopia. Journal of Environmental and Public Health; 2021, Article ID 4680573, 8 pages.

Ayano G, Yohannis K, Abraha M (2019) Epidemiology of khat (Catha edulis) consumption among university students: a meta-analysis. BMC Public Health 19:150

Baba H, Tsuneyama K, Yazaki M, Nagata K, Minamisaka T, Tsuda T et al (2013) The liver in itai-itai disease (chronic cadmium poisoning): pathological features and metallothionein expression. Mod Pathol 26(9):1228-1234

Badego B, Yoseph A, Astatkie A (2020) Prevalence and risk factors of hypertension among civil servants in Sidama Zone, south Ethiopia. PloS one;15(6):e0234485

Bearer CF, O'Riordan MA, Powers R (2000) Lead exposure from blood transfusion to premature infants. J Pediatr 137:549-554

Belayneh Z, Mekuriaw B (2019) Prevalence and associated factors of Khat chewing among people with HIV/AIDS at rural health centers of Ethiopia: a cross-sectional study. Research Square; 2019. https://doi.org/10. 21203/rs.2.14394/v1.

Belwal R, Teshome H (2011) Chat exports and the Ethiopian economy: opportunities, dilemmas and constraints. Afr J Bus Manage 5:3635-3648

Bempah CK, Buah-Kwofie A, Enimil E, Blewu B, Agyei-Martey G (2012) Residues of organochlorine pesticides in vegetables marketed in Greater Accra Region of Ghana. Food Control 25(2):537-542

Bennani A, Mohamed S (2021) Effect of Khat consumption on oral health: study carried out in Djibouti City. Oral Health Dental Sci 5:1-8

Birhane BW, Birhane MW (2014) The effect of Khat (Catha edulis) chewing on blood pressure among male adult Chewers, Bahir Dar, North West Ethiopia. Sci J Public Health 2(5):461-468

Breast Cancer Fund Organization (2004) Chemical Fact Sheets: Organochlorine Pesticides (Chrlordane, DDT/DDE/DDD, Heptachlor, Lindane, Mirex). https://web.archive.org/web/20061009104100/http://www.breas tcancerfund.org/site/pp.asp? $c=k w K X L d P a E \& b=84567$ (Accessed 22 ${ }^{\text {nd }}$ August, 2021).

Cabello G, Juarranz A, Botella LM, Calaf GM (2003) Organophosphorous pesticides in breast cancer progression. J Submicrosc Cytol Pathol 35:1-9

Carrier N (2008) Is miraa a drug?: Categorizing Kenyan khat. Subst Use Misuse 43:803-818

Centers for Disease Control and Prevention (CDC) Low Level Lead Exposure Harms Children. A Renewed Call for Primary Prevention. 2012. Accessed 22nd August 2021)

Chowdhury R, Ramond A, O'Keeffe LM, Shahzad S, Kunutsor SK, Muka T, Gregson J, Willeit P, Warnakula S, Khan H, Chowdhury S, Gobin R, Franco OH, Di Angelantonio E (2018) Environmental toxic metal contaminants and risk of cardiovascular disease: systematic review and meta-analysis. BMJ 362(k3310):1-13. https://doi.org/10.1136/bmj.k3310

Chuka A, Gutema BT, Ayele G, Megersa ND, Melketsedik ZA, Zewdie TH (2020) Prevalence of hypertension and associated factors among adult residents in Arba Minch Health and Demographic Surveillance Site, Southern Ethiopia. PLoS ONE 15(8):e0237333

Canfield RL, Jusko TA, Kordas K (2005) Environmental lead exposure and children's cognitive function. Ital J Pediatr 31:293-300
Cesbron A, Saussereau E, Mahieu L, Couland I, Guerbet M, Goullé J-P (2013) Metallic profile of whole blood and plasma in a series of 106 healthy volunteers. J Anal Toxicol 37:401-405

Cusick SE, Jaramillo EG, Moody EC, Ssemata AS, Bitwayi D, Lund TC, Mupere E (2018) Assessment of blood levels of heavy metals including lead and manganese in healthy children living in the Katanga settlement of Kampala, Uganda. BMC Public Health 18:717-717

Daba D, Hymete A, Bekhit AA, Mohamed AMI, Bekhit AE-DA (2011) Multi residue analysis of pesticides in wheat and khat collected from different regions of Ethiopia. Bull Environ Contam Toxicol 86(3):336-341

Dagne E, Adugna Y, Kebede E, Atilaw Y (2010) Determination of Levels of Cathine in Khat (Catha edulis) leaves and its detection in urine of khat chewers: a preliminary report. Ethiop e-J Res Innovat Foresight 2(1):7-22

De Flora S, Bonanni P (2011) The prevention of infection-associated cancers. Carcinogenesis 32(6):787-795

Defar A, Getachew T, Teklie H, Bekele A, Gonfa G, Gelibo T et al (2017) Tobacco use and its predictors among Ethiopian adults: A further analysis of Ethiopian NCD STEPS survey-2015. Ethiop J Health Dev. https://doi.org/ 10.4314/EJHD.V3111

Derso AG, Dagnew GG (2019) Exposure and Health Risk Assessment of Farmers to DDT during Khat Production in Chiro Woreda, West Hararghe Zone Ethiopia. World J Agric Res. https://doi.org/10.12691/wjar-7-1-6

Dessie G, Kinlund P (2008) Khat expansion and forest decline in Wondo Genet, Ethiopia. Geografiska Annaler: Series B, Human Geography 90:187-203

Desta A, Ataklti A (2015) Profile of essential and non-essential metals in soil and in khat (Catha Edulis Forsk) leaves cultivated in Southern Region, Ethiopia. Am J Phys Chem 4:58-64. https://doi.org/10.4172/2150-3494. 1000107

Drimie S, Pereira L (2016) Chapter one_advances in food security and sustainability in South Africa. In: Barling D (ed) Advances in food security and sustainability, vol 1. Elsevier, New York, pp 1-31

Djurasevic S, Todorovic Z, Pavlovic S, Pejic S (2019) Cadmium and fullerenes in liver diseases. Dietary Interventions in Liver Disease. Elsevier; pp 333-44

Dobson AW, Erikson KM, Aschner M (2004) Manganese neurotoxicity. Ann NY Acad Sci 1012:115-129

Dudai N, Fischer R, Segev D, Chaimovitsh D, Rosenzweig N, Shimoni M (2006) Antioxidative activity of khat (Catha edulis Forsk.). II International Symposium on Natural Preservatives in Food, Feed, and Cosmetics 778:85-92

Egger AE, Grabmann G, Gollmann-Tepeköylü C, Pechriggl EJ, Artner C, Türkcan A et al (2019) Chemical imaging and assessment of cadmium distribution in the human body. Metallomics 11(12):2010-2019

Eskenazi B, Marks AR, Bradman A, Fenster L, Johnson C, Barr DB, Jewell NP (2006) In utero exposure to dichlorodiphenyltrichloroethane (DDT) and dichlorodiphenyldichloroethylene (DDE) and neurodevelopment among young Mexican American children. Pediatrics 118(1):233-241

Feyisa TH, Aune JB (2003) Khat expansion in the Ethiopian highlands. Mt Res Dev 23:185-189

Fenta A, Kidanemariam A (2015) Profile of essential and non-essential metals in soil and in Khat (Catha edulis Forsk) leaves cultivated in Southern Region. Chem Sci J. https://doi.org/10.4172/2150-3494.1000107

Flora G, Gupta D, Tiwari A (2012) Toxicity of lead: a review with recent updates. Interdiscip Toxicol 5(2):47-58

Fossi MC, Coppola D, Baini M, Giannetti M, Guerranti C, Marsili L, Panti C, de Sabata E, Clò S (2014) Large filter feeding marine organisms as indicators of microplastic in the pelagic environment: the case studies of the Mediterranean basking shark (Cetorhinus maximus) and fin whale (Balaenoptera physalus). Mar Environ Res 100:17-24

Garner RE, Levallois P (2017) Associations between cadmium levels in blood and urine, blood pressure and hypertension among Canadian adults. Environ Res 155:64-72

Garabrant DH, Held J, Langholz B, Peters JM, Mack TM (1992) DDT and related compounds and risk of pancreatic cancer. J Natl Cancer Inst 84(10):764-771

Gebrehiwot M, Elbakidze M, Lidestav G, Sandewall M, Angelstam P, Kassa H (2016) From self-subsistence farm production to khat: driving forces of change in Ethiopian agroforestry homegardens. Environ Conserv 43:263

Gebissa E (2008) Scourge of life or an economic lifeline? Public discourses on khat (Catha edulis) in Ethiopia. Subst Use Misuse 43:784-802 
Gebrie A, Alebel A, Zegeye A, Tesfaye B (2018) Prevalence and predictors of khat chewing among Ethiopian university students: a systematic review and meta-analysis. PLoS ONE 13:e0195718

Genchi G, Sinicropi MS, Lauria G, Carocci A, Catalano A (2020) The effects of cadmium toxicity. Int J Environ Res Public Health 17(11):26

Geta TG, Woldeamanuel GG, Hailemariam BZ, Bedada DT (2019) Association of chronic khat chewing with blood pressure and predictors of hypertension among adults in Gurage Zone, Southern Ethiopia: a comparative study. Integr Blood Press Control 12:33

Getahun W, Gedif T, Tesfaye F (2010) Regular Khat (Catha edulis) chewing is associated with elevated diastolic blood pressure among adults in Butajira, Ethiopia: a comparative study. BMC Public Health 10(1):1-8

Gezon LL (2012) Drug crops and food security: the effects of khat on lives and livelihoods in northern madagascar. Culture Agric Food Environ 34(2):124-135

Gezon LL (2017) Beyond (anti) utilitarianism: khat and alternatives to growth in northern Madagascar. J Polit Ecol 24:582-594

Gorfu M (2006) The prevalence of Khat-induced psychotic reactions among college students: a case in Jimma University College of agriculture. Ethiop J Educ Sci. https://doi.org/10.4314/EJESC.V2I1.41977

Gorsky M, Epstein JB, Levi H, Yarom N (2004) Oral white lesions associated with chewing khat. Tob Induc Dis 2(3):1-6

Gudata ZG, Cochrane L, Imana G (2019) An assessment of khat consumption habit and its linkage to household economies and work culture: the case of Harar city. PLOS ONE 14:e0224606

Gudina EK, Michael Y, Assegid S (2013) Prevalence of hypertension and its risk factors in southwest Ethiopia: a hospital-based cross-sectional survey. Integr Blood Press Control 6:111-117

Hassan AA, Abdullah SM, Khardali IA, Oraiby ME, Shaikain GA, FageehM, and Almousa F, (2016) Health impact of khat chewing and pesticides: detection of 8 pesticides multi-residues in khat leaves (Catha edulis) from Jazan Region, KSA. Adv Environ Biol 10(8):30

Haye TB, Tolera Agama B (2020) Prevalence of Hypertension and Associated Factors among the Outpatient Department in Akaki Kality Subcity Health Centers, Addis Ababa, Ethiopia. Int J Hypertens; 2020

Heidelbaugh JJ, Bruderly M (2006) Cirrhosis and chronic liver failure: part I. Diagnosis and evaluation 2006. Am Family Phys 74(5):756-62

Hailemariam T, Belete T, Hailu T, Ayele D, Ligani S (2018) Quantification of organochlorine pesticide residues in chewable part of chata edulus in gurage zone, SNNPR. Ethiop J Anal 9:1000395

Huang M, Long L, Deng M, Yu Z, Qu H, Tan L et al (2021) Effectiveness and safety of Yufeng Ningxin for the treatment of essential hypertension: A protocol for systematic review and meta-analysis. Med (Baltimore) 100(9):e24858

Ibrahim MM, Damasceno A (2012) Hypertension in developing countries. The Lancet 380(9841):611-619

Jayed D, Al-Huthi MA (2016) Khat Chewing Induces Cardiac Arrhythmia. Open Access Library J. https://doi.org/10.4236/oalib.1102809

Järup $L$ (2003) Hazards of heavy metal contamination. Br Med Bull 68:167-182

Jomova K, Jenisova Z, Feszterova M, Baros S, Liska J, Hudecova D, Rhodes CJ, Valko M (2011) Arsenic: toxicity, oxidative stress and human disease. J Appl Toxicol 31:95-107

Jose A, Ray JG (2018) Toxic heavy metals in human blood in relation to certain food and environmental samples in Kerala, South India. Environ Sci Pollut Res 25:7946-7953

Karri V, Schuhmacher M, Kumar V (2016) Heavy metals (Pb, Cd, As and MeHg) as risk factors for cognitive dysfunction: A general review of metal mixture mechanism in brain. Environ Toxicol Pharmacol 48:203-213

Kandari LS, Yadav HR, Thakur AK, Kandari T (2014) Chat (Catha edulis): A socio economic crop in Harar Region, Eastern Ethiopia. Springerplus 3:1-9

Kang M-Y, Cho S-H, Lim Y-H, Seo J-C, Hong Y-C (2013) Effects of environmental cadmium exposure on liver function in adults. Occup Environ Med 70(4):268-273

Karunamoorthi K, Mohammed M, Wassie F (2012) Knowledge and practices of farmers with reference to pesticide management: implications on human health. Arch Environ Occup Health 67(2):109-116

Kassa A, Woldesemayat EM (2019) Hypertension and diabetes mellitus among patients at Hawassa University comprehensive specialized hospital, Hawassa, Southern Ethiopia. International journal of chronic diseases;2019.
Kassab A, Al Moustafa A-E (2017) Role of Qat chewing and mate consumption in human oral carcinogenesis. Dev Oral Cancer. https://doi.org/10.1007/ 978-3-319-48054-1_9

Kassim S, Dalsania A, Nordgren J, Klein A, Hulbert J (2015) Before the ban-an exploratory study of a local khat market in East London, UK. Harm Reduct J 12(1):1-9

Kaoud HA (2015) Article review: heavy metal and pesticides in aquaculture: health problems. Eur J Acad Essays 2:15-22

Kebede B, Ayele G, Haftu D, Gebremichael G (2020) The prevalence and associated factors of hypertension among adults in Southern Ethiopia. Int J Chronic Dis; 2020

Keil DE, Berger-Ritchie J, McMillin GA (2011) Testing for Toxic Elements: A Focus on Arsenic, Cadmium, Lead, and Mercury. Laboratory Medicine 42:735-742

Ketema T, Yohannes M, Alemayehu E, Ambelu A (2015) Evaluation of immunomodulatory activities of methanolic extract of khat (Catha edulis, Forsk) and cathinone in Swiss albino mice. BMC Immunol 16:1-11

Krueger J, Mutyambai D (2020) Restricting pesticides on a traditional crop: the example of khat (Catha edulis) and the Njuri Ncheke of Meru, Kenya. Ecology and Society;25(4).

Kinuthia GK, Ngure V, Beti D, Lugalia R, Wangila A, Kamau L (2020) Levels of heavy metals in wastewater and soil samples from open drainage channels in Nairobi, Kenya: community health implication. Sci Rep 10:8434

Kumar A, Cabral-Pinto MMS, Chaturvedi AK, Shabnam AA, Subrahmanyam G, Mondal, Gupta DK, Malyan SK, Kumar SS, Khan SA and Yadav KK (2020) Lead Toxicity: Health hazards, influence on food chain, and sustainable remediation approaches. Int J Environ Res Public Health; 17(7), 2179; https://doi.org/10.3390/ijerph17072179

Lamina RM, Lamina S (2013) The Chewing of Khat (Catha Edulis) in the horn of Africa and Arabian Peninsula: economic overview. Arab J Bus Manag Rev (OMAN Chapter) 3(2):80-89

Lemaire G, Mnif W, Mauvais P, Balaguer P, Rahmani R (2006) Activation of aand $\beta$-estrogen receptors by persistent pesticides in reporter cell lines. Life Sci 79:1160-1169

Leon ME, Assefa M, Kassa E, Bane A, Gemechu T, Tilahun Y, et al. (2017) Qat use and esophageal cancer in Ethiopia: A pilot case-control study. PloS one;12(6):e0178911.

Leyssens L, Vinck B, Van Der Straeten C, Wuyts F, Maes L (2017) Cobalt toxicity in humans - a review of the potential sources and systemic health effects. Toxicology 387:43-56

Lia X, Brejnrod AD, Ernst M, Rykære M, Herschenda J, Olsen NMC, Dorrestein PC, Rensing C, Sørensen SJ (2019) Heavy metal exposure causes changes in the metabolic health-associated gut microbiome and metabolites. Environ Int 126:454-467

Lu Y, Li Y, Xiang M, Zhou J, Chen J (2017) Khat promotes human breast cancer MDA-MB-231 cell apoptosis via mitochondria and MAPK-associated pathways. Oncol Lett 14(4):3947-3952

Mandi G. Miraa a Gold Platter in Taita Taveta County. Kwaela News Network. 2019. https://kwaela.co.ke/miraa-a-gold-platter-in-taita-taveta-county/. Accessed 3rd August, 2021

Mohammed A, Engidawork E (2011) Reproductive parameters are differentially altered following subchronic administration of Catha edulis F. (Khat) extract and cathinone in male rats. J Ethnopharmacol 134:977-983

Mahamoud HD, Muse SM, Fader T, Roberts LR, Fischer PR, Torbenson MS (2016) Khat chewing and cirrhosis in Somaliland: case series. Afr J Prim Health Care Family Med 8(1):1-4

Mekuria W (2018) Public discourse on Khat (Catha edulis) production in Ethiopia: review. J Agric Extens Rural Dev 10(10):192-201

Makeen A, Al-Faify A, Elreffaey S (2021) A Qualitative study to assess the competencies of women living in faifa mountains to help men for withdrawal of chewing khat habit; Jazan Region, Saudi Arabia. Egypt Soc Clin Toxicol J. https://doi.org/10.21608/esctj.2021.156305.

Masiá A, Vásquez K, Campo J, Picó Y (2015) Assessment of two extraction methods to determine pesticides in soils, sediments and sludges. Application to the Túria River Basin. J Chromatogr A;1378:19-31.

Masoud AM, Al-Shehari BA, Al-Hattar LN, Altaezzi MA, Al-khadher WA, Zindal YN (2012) Alterations in Antioxidant Defense System in the Plasma of Female Khat Chewers of Thamar City, Yemen. Jord J Biol Sci 5(2):129-133 
Matloob M (2003) Determination of cadmium, lead, copper and zinc in Yemeni khat by anodic stripping voltammetry. Eastern Mediterran Health J 9(1-2):28-36

Meftaul IM, Venkateswarlu K, Dharmarajan R, Annamalai P, Megharaj M (2020) Pesticides in the urban environment: A potential threat that knocks at the door. Science of The Total Environment;711:134612.

Mekuriaw B, Belayneh Z, Yitayih Y (2020) Magnitude of Khat use and associated factors among women attending antenatal care in Gedeo zone health centers, southern Ethiopia: a facility based cross sectional study. BMC Public Health 20:1-8

McKnight US, Rasmussen JJ, Kronvang B, Binning PJ, Bjerg PL (2015) Sources, occurrence and predicted aquatic impact of legacy and contemporary pesticides in streams. Environ Pollut 200:64-76

Megerssa B, Esayas A, Mohamed A (2014) Socio-economic impact of khat in Mana district, Jimma zone, south western Ethiopia. Discourse J Agric Food Sci 2:21-32

Miller PD, Kendrick D, Coupland C, Coffey F (2010) The use of conspicuity aids by cyclists and risk of crashes involving other road users: a protocol for a population based case-control study. BMC Public Health 10(1):1-6

Mohammed A, Engidawork E (2011) Reproductive parameters are differentially altered following subchronic administration of Catha edulis $F$ (Khat) extract and cathinone in male rats. J Ethnopharmacol 134:977-983

Molla Z, Dube L, Krahl W, Soboka M (2017) Tobacco dependence among people with mental illness: a facility-based cross sectional study from Southwest Ethiopia. BMC Res Notes 10(1):1-7

Morse DE, Psoter WJ, Cleveland D, Cohen D, Mohit-Tabatabai M, Kosis DL et al (2007) Smoking and drinking in relation to oral cancer and oral epithelial dysplasia. Cancer Causes Control 18(9):919-929

Naji KM, Al-Maqtari MA, Al-Asbahi AA, Abdullah QYM, Babu RN, Devaraj VR (2015) Effect of daily chewing soft buds and leaves of Catha edulis (Khat) on the antioxidant defense system and oxidative stress markers in blood. Arab J Sci Eng 40(1):1-6

Nasher AT, Al-Hebshi NN, Al-Moayad EE, Suleiman AM (2014) Viral infection and oral habits as risk factors for oral squamous cell carcinoma in Yemen: a case-control study. Oral Surg Oral Med Oral Pathol Oral Radiol 118(5):566-572.e1

Nicolopoulou-Stamati P, Maipas S, Kotampasi C, Stamatis P, Hens L (2016) Chemical pesticides and human health: the urgent need for a new concept in agriculture. Front Public Health 4:148-155. https://doi.org/ 10.3389/fpubh.2016.00148

Nigatu A, Libsu S (2019). Studies on the effects of extracts of fresh khat/catha edulis leaves on the oxidation of niger seed oil. J Pharm Pharmacol. https://doi.org/10.17265/2328-2150/2019.07.007

Niriayo YL, Ibrahim S, Kassa TD, Asgedom SW, Atey TM, Gidey K et al (2019) Practice and predictors of self-care behaviors among ambulatory patients with hypertension in Ethiopia. PLoS ONE 14(6):e0218947

Njiru N, Muluvi A, Owuor G, Langat J (2013) Effects of khat production on rural household's income in Gachoka Division Mbeere south district Kenya. J Econ Sustain Dev 4:54-63

Njuguna J, Olieva S, Muruka C, Owek C (2013) Khat consumption in Masalani town, northeastern Kenya. J Psychoactive Drugs 45:355-359

Nyachieo A, Kiraithe MM, Spiessens C, Chai DC, Kiulia NM, D'hooghe TM and Mwenda JM, (2013) Short-term effects of high-dose khat on sperm parameters and reproductive hormonal levels in olive baboons (Papio anubis). Gynecol Obstet Invest 75:109-114

Offor SJ, Orish CN, Chidi EE, Frazzoli C and Orisakwe OE (2021) Blood donation and heavy metal poisoning in developing nations: Any link? Transfusion and Apheresis Science; 60:103067.

Oliver-Williams C, Howard AG, Navas-Acien A, Howard BV, Tellez-Plaza M, Franceschini N (2018) Cadmium body burden, hypertension, and changes in blood pressure over time: results from a prospective cohort study in American Indians. J Am Soc Hypertens. https://doi.org/10. 1016/j.jash.2018.03.002

Olovi MB, Krsti DZ, Lazarevi -Pati TD, Bond AM and Vasi VM, (2013) Acetylcholinesterase Inhibitors: Pharmacology and Toxicology. Curr Neuropharmacol 11:315-335

Omare MO (2020) Contemporary trends in the use of Khat for Recreational purposes and Its possible Health implications. Open Access Library J. https://doi.org/10.4236/oalib.1106985

Ongeri L, Kirui F, Muniu E, Manduku V, Kirumbi L, Atwoli L, Agure S, Wanzala P, Kaduka L, Karimi M (2019) Khat use and psychotic symptoms in a rural
Khat growing population in Kenya: a household survey. BMC Psychiatry 19:1-10

Orlien SMS, Sandven I, Berhe NB, Ismael NY, Ahmed TA, Stene-Johansen K et al (2018) Khat chewing increases the risk for developing chronic liver disease: a hospital-based case-control study. Hepatology 68(1):248-257

Oyugi AM, Korir BK, Kibet JK, Ngari SM (2021) The possible abuse of catha edulis and its associated health and socio-economic Impacts. Prog Chem Biochem Res 4(2):234-253

Patel NB (2015) "Natural Amphetamine" Khat: a cultural tradition or a drug of abuse? Int Rev Neurobiol 120:235-255

Palmatier RW, Houston MB, Hulland J (2017) Review articles: purpose, process, and structure. J Acad Mark Sci 46(1):1-5. https://doi.org/10.1007/ s11747-017-0563-4

Pickering R (2010) Re intoxication with Qaat, Catha edulis L. J Forensic Leg Med 17:404

Pizarro F, Olivares M, Gidi V, Araya M (1999) The Gastrointestinal tract and acute effects of copper in drinking water and beverages. Rev Environ Health 14(4):231-237

Pizzorno, J. (2015). Conventional Laboratory Tests to Assess Toxin Burden. Integrative medicine (Encinitas, Calif.), 14, 8-16.

Ram H, Sarkar J, Kumar H, Konwar R, Bhatt M, Mohammad S (2011) Oral cancer: risk factors and molecular pathogenesis. J Maxillofac Oral Surg 10(2):132-137

Regassa C, Tolcha T, Gomoro K, Megersa N (2020) Determination of residue levels of DDT and its metabolites in khat and cabbage samples using QUEChERS sample preparation method combined with GC-MS detection. Ethiop J Sci Sustain Dev. https://doi.org/10.20372/EJSSDASTU:V7. 11.2020.119.

Regassa G, Regassa C (2018) Assessment of pesticides handling practices and health and environmental impacts on Khat growing farmers: in Haromaya Woreda, Eastern Ethiopia. Int J Adv Eng Res Sci 5(12):252-263

Regassa G, Regassa C (2021) Knowledge and attitude of Khat growing farmers on the safe use and handling of pesticides in Haromaya Wereda, Oromia Regional State, Eastern Ethiopia. Afr J Environ Sci Technol 15(1):16-26

Richardson JR, Fitsanakis V, Westerink RH, Kanthasamy AG (2019) Neurotoxicity of pesticides. Acta Neuropathol 138(3):343-362

Ruder HL (2018) Impact of khat production on household welfare in Amhara region of Ethiopia. https://krex.k-state.edu/dspace/handle/2097/38888. Accessed 3rd August, 2021.

Sadeq-Ali A.M and AlAkhali M (2017) Oral hygiene and periodontal health status among khat chewers. A case-control study. J Clin Exp Dentist; 9: e629.

Saha P, Paul B (2019) Assessment of heavy metal toxicity related with human health risk in the surface water of an industrialized area by a novel technique. Hum Ecol Risk Assess Int J 25:966-987

Sane MR, Malukani K, Kulkarni R, Varun A (2018) Fatal Iron Toxicity in an Adult: Clinical Profile and Review. Indian J Crit Care Med 22(11):801-803

Santos G, Borges JMP, Avila-Rogrigues M, Giano SB, Barreto GE, Rubio EP, Aguiar RM, Galambeck E, Bromochenkel CB, de Oliveira DM (2019) Copper and neurotoxicity in autism spectrum disorder. Curr Pharm Des 25(8):4747-4754

Schmidt-Westhausen A, Al Sanabani J, Al-Sharabi A (2014) Prevalence of oral white lesions due to qat chewing among women in $Y$ emen. Oral Dis 20(7):675-681

Sinba $E$ (2017) Addressing the high prevalence of smokeless tobacco use in pastoralist communities of ethiopia's adult: a call to action. SM Addict Res Ther; 1(1): 1002s2.

Seufert V, Ramankutty N, Mayerhofe T (2017) What is this thing called organic? - How organic farming iscodified in regulations. https://doi.org/10. 14288/1.0378888

Suhartono E, Leksono AS, Djati MS (2014) Oxidative stress and kidney glycation in rats exposed cadmium. Int J Chem Eng Appl 5(6):497

Subramaniam K, Solomon J (2006) Organochlorine pesticides BHE and DDE in human blood in and around Maduarai. India Indian J Clin Biochem 21(2):169-172

Swaddiwudhipong W, Mahasakpan P, Limpatanachote P, Krintratun S (2010) Correlations of urinary cadmium with hypertension and diabetes in persons living in cadmium-contaminated villages in northwestern Thailand: a population study. Environ Res 110(6):612-616 
Syngenta (2013) Safety data sheet according to registration number (CE) 1907/2006. http://www3.syngenta.com/country/ro/SiteCollectionD ocuments/Protectia-Plantelor/Fise de siguranta/2015/Fișa de securitate Actellic.pdf. Accessed 22nd August, 2021

Teklie H, Gonfa G, Getachew T, Defar A, Bekele A, Bekele A, Gelibo T, Amenu K, Taddele T, Taye G (2017) Prevalence of Khat chewing and associated factors in Ethiopia: findings from the 2015 national Non-communicable diseases STEPS survey. Ethiop J Health Dev 31:320-330

Tadesse SF, Kebede WL (2015) Determination of the Level of Selected Heavy Metals from Khat Leaves (Cata Edulis Forsk) Grown in Gidolle Konso and Koyira, Southern Ethiopia. Science Journal of Analytical Chemistry 3(6):115-121

Tarboush NA, Al Masoodi O, Al Bdour S, Sawair F, Hassona Y (2019) Antioxidant capacity and biomarkers of oxidative stress in saliva of khat-chewing patients: a case-control study. Oral Surg Oral Med Oral Pathol Oral Radiol 127(1):49-54

Tchounwou PB, Patlolla AP, Yedjou CG and Moore PD (2015) Environmental Exposure and Health Effects Associated with Malathion Toxicity, In: Toxicity and Hazards of Agrochemicals. Edited by Larramendy ML, and Solonesky S. Chapter 3. ISBN: 978-953-51-5403-7. https://doi.org/10. 5772/60911

Tessema ZT, Zeleke TA (2020) Spatial Distribution and Factors Associated with Khat Chewing among Adult Males 15-59 Years in Ethiopia Using a Secondary Analysis of Ethiopian Demographic and Health Survey 2016: Spatial and Multilevel Analysis. Psychiatry J 2020.

Tiemann U (2008) In vivo and in vitro effects of the organochlorine pesticides DDT, TCPM, methoxychlor, and lindane on the female reproductive tract of mammals: a review. Reprod Toxicol 25:316-326

Tinkov AA, Gritsenko VA, Skalnaya MG, Cherkasov SV, Aaseth J, Skalny AV (2018) Gut as a target for cadmium toxicity. Environ Pollut 235:429-434

Tiryaki O, Temur C (2010) The fate of pesticide in the environment. J Biol Environ Sci 4(10):29-38

Thomas, S and Williams T (2013) Khat (Catha edulis): a systematic review of evidence and literature pertaining to its harms to UK users and society. Drug Science, Policy and Law; 1, 2050324513498332.

Tsochatzis EA, Bosch J, Burroughs AK (2014) Liver cirrhosis. The Lancet 383(9930):1749-1761

Udo de Haes, HA and de Snoo GR (2010) 19 - Eco-labelling of agricultural food products. In: Environmental Assessment and Management in the Food Industry, U. Sonesson, J. Berlin and F. Ziegler, Eds, Woodhead Publishing, pp. 374-397.

Vorkamp K, Rigét FF (2014) A review of new and current-use contaminants in the Arctic environment: evidence of long-range transport and indications of bioaccumulation. Chemosphere 111:379-395. https://doi.org/ 10.1016/j.chemosphere.2014.04.019

Wani AL, Ara A, Usmani JA (2015) Lead toxicity: a review. Interdisc Toxicol 8:55-64

Wallace DR (2015) Environmental pesticides and heavy metals-role in Breast Cancer. In: Larramendy ML, Solonesky S (eds) Toxicity and hazards of agrochemicals. Chapter 2. ISBN: 978-953-51-5403-7. https://doi.org/10 $5772 / 60779$

Warnakulasuriya S (2009) Causes of oral cancer-an appraisal of controversies. Br Dent J 207(10):471-475

Weyesa GW (2021) Practices and challenges of pestiside application on KHat Farm, the case of Kersa Woreda, Jimma Zone, south West Ethiopia. Sci Dev 2(1):7-14

White KMR, Anderson Berry AL, White SF, Moran D, Lyden E, Bearer CF (2019) Donor blood remains a source of heavy metal exposure. Pediatr Res 85:4-5
Widler P, Mathys K, Brenneisen R, Kalix P, Fisch HU (1994) Pharmacodynamics and pharmacokinetics of khat: a controlled study. Clin Pharmacol Ther 55:556-562

World Health Organization (WHO) (2013) Control of neglected tropical diseases who pesticide evaluation scheme. https://apps.who.int/iris/bitst ream/handle/10665/90976/9789241506304_eng.pdf?sequence=1. (Accessed 22 ${ }^{\text {nd }}$ August, 2021)

World Health Organization (WHO) (2019) Lead poisoning and health. https:// www.who.int/news-room/fact-sheets/detail/lead-poisoning-andhealth. Accessed on 20th August 2021.

Woldamanuel MM (2019) Assessment of selected nutrients and toxic chemicals in ethiopian khat. Sci J Chem 7(1):26-35. https://doi.org/10.11648/j. sjc.20190701.15

Woldetsadik D, Simon MP, Knuth D, Hailu H, Gebresilassie A, Dejen A, et al. (2021) Exposure to DDT and HCH congeners and associated potential health risks through khat (Catha edulis) consumption among adults in South Wollo, Ethiopia. Environ Geochem Health. https://doi.org/10. 1007/s10653-021-00846-w

Wondemagegn AT, Cheme MC, Kibret KT (2017) Perceived Psychological, Economic, and Social Impact of Khat Chewing among Adolescents and Adults in Nekemte Town, East Welega Zone. West Ethiopia Biomed Res Int 2017:7427892

Wuana, R. A. and Okieimen, F. E. (2011). Heavy Metals in Contaminated Soils: A Review of Sources, Chemistry, Risks and Best Available Strategies for Remediation. ISRN Ecology, 2011, 402647.

Wu H, Liao Q, Chillrud SN, Yang Q, Huang L, Bi J et al (2016) Environmental exposure to cadmium: health risk assessment and its associations with hypertension and impaired kidney function. Sci Rep 6(1):1-9

Yadeta TA, Egata G, Seyoum B, Marami D (2020) Khat chewing in pregnant women associated with prelabor rupture of membranes, evidence from eastern Ethiopia. Pan Afr Med J 1(36):1

Yahya A, Rajeshwar Y, Eticha T, Kahsay G, Ali D, Gebretsadik H, Gebretsadik T and Janapati YK (2016). Socio-economic and health effects of khat chewing in Mekelle, Tigray Region, Ethiopia. https://ijppr.humanjourn als.com/socio-economic-and-health-effects-of-khat-chewing-in-mekel le-tigray-region-ethiopia/ (Accessed $3^{\text {rd }}$ August, 2021).

Yang CS, Chen XL (2020) Research on esophageal cancer: with personal perspectives from studies in China and Kenya. Int J Cancer 149(2):264-276

Yarom N, Epstein J, Levi H, Porat D, Kaufman E, Gorsky M (2010) Oral manifestations of habitual khat chewing: a case-control study. Oral Surg Oral Med Oral Pathol Oral Radiol Endodontol 109(6):e60-e66

Yimer A, Khan M (2015) Determination of iron, cobalt, chromium and copper metals in commercially available Khat (Catha Edulis Forsk) in Arba Minch, Ethiopia. J Eng Res Appl 5(1):66-74

Yin L, Dai Q, Jiang P, Zhu L, Dai H, Yao Z, Liu H, Ma X, Qu L, Jiang J (2018) Manganese exposure facilitates microglial JAK2-STAT3 signaling and consequent secretion of TNF-a and IL-1 $\beta$ to promote neuronal death. Neurotoxicology 64:195-203

Yitayih Y, van Os J (2021) Prevalence and determinants of chewing khat among women in Ethiopia: data from Ethiopian demographic and health survey 2016. BMC Psychiatry 21:127

Yuvaraj M, Mahendran PP, Hussien ET (2020) Role of organic farming in agriculture. Organ Agric Shaon Kumar Das IntechOpen. https://doi.org/10. 5772/intechopen.93431

\section{Publisher's Note}

Springer Nature remains neutral with regard to jurisdictional claims in published maps and institutional affiliations. 